Min

19,2

1. 1 (n) (1)

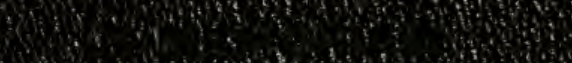

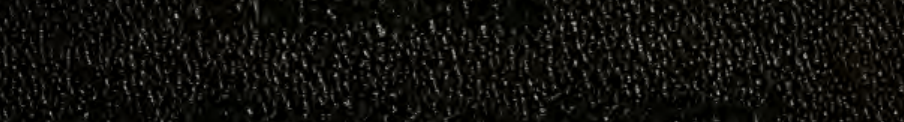
(1) 196 ?

His 1040

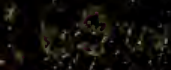
fintitis 


\section{The Zibrary}

of the

annibersity of 3 Porth Carolina

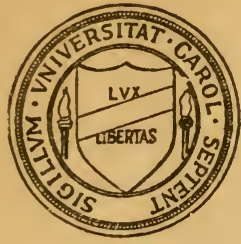

This book was presentei

by

haurence Sprunt

$C B$

S769w 
UNIVERSITY OF N.C. AT CHAPEL HILL

|| ||| || ||| |||||||||||||||||||||||||

\section{This book must , be taken from t Library building.}






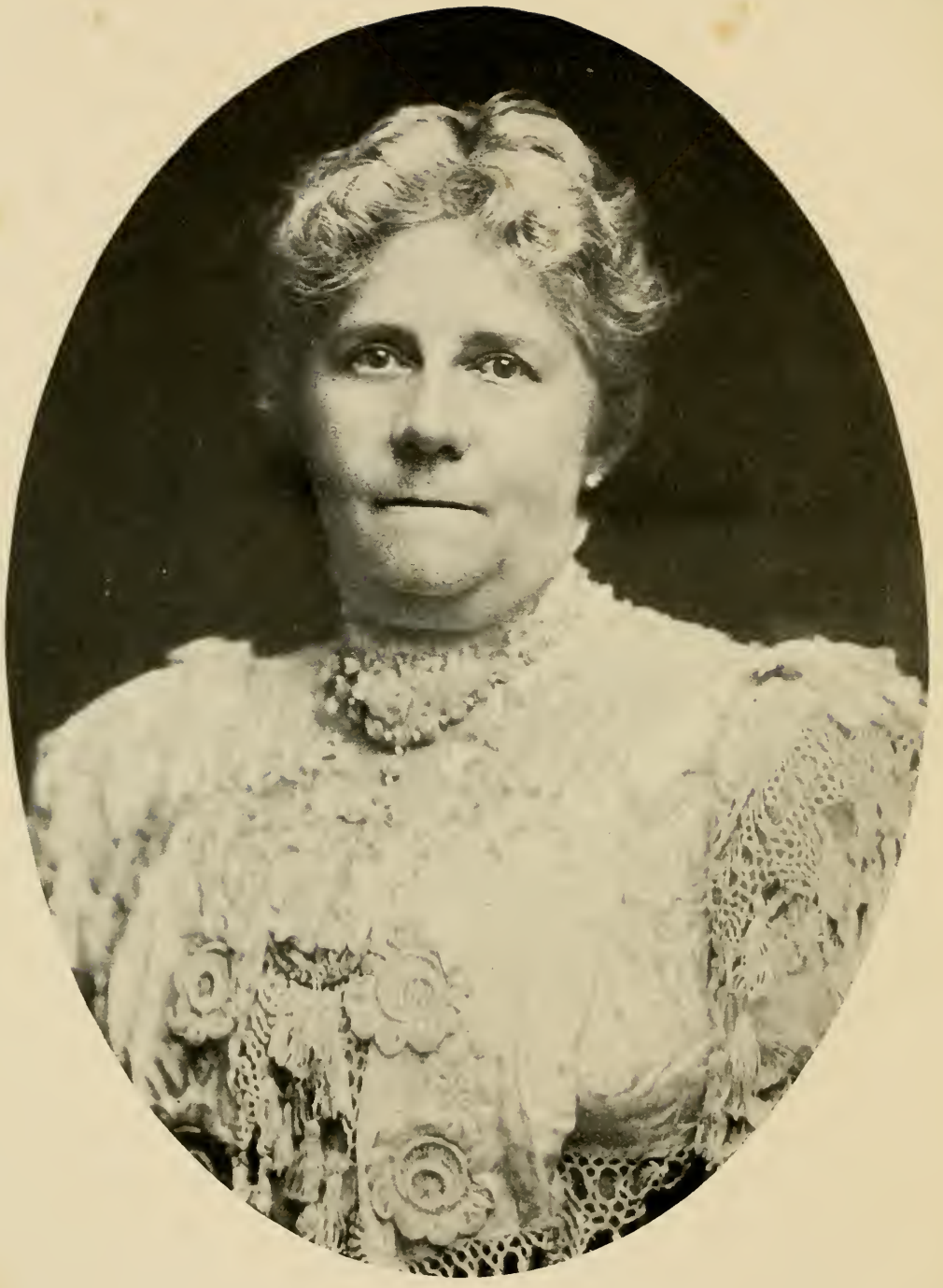

MRS. JAMES SPRUNT 


\section{In Memoriam \\ fttrs. James Sprunt}

"And a book of remembrance was written before Him for them that feared the Lord, and that thought upon His name. And they shall be Mine, saith the Lord of Hosts, in that day when I make up My jewels." -Malachi 3:16, 17. 
Copyright, 1916, by

JAmes SPRUnT

Compiled and edited by Ellen Hale WilsoN 


\section{解edication}

This lowing record of the devoted, consecrated life

of

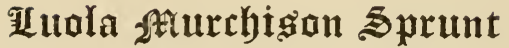

is affectionately inscribed to our infant grandson

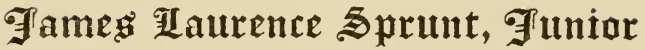

whose sweet and gentle mother

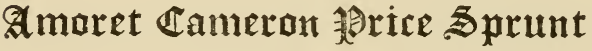

died at the age of twenty-four years, when she gave him birth.

His little life, trembling like a star between two worlds, was mercifully spared to brighten and bless the last year on earth of his devoted grandmother, who brought him to our home and hearts and lavished upon him the matchless tenderness of a mother's love. It is my daily prayer that he may be brought up in the nurture and admonition of the Lord, and that in due time he may be cailed to the ministry of the blessed gospel of Christ, to which his grandmother and I have prayerfully commended him. 



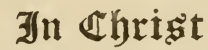

"Death may hide, but it cannot divide;

Thou art but on Christ's other side;

'Thou art with Christ and $\mathrm{He}$ with me, In Christ united still are we."

\section{In fitemariam}

In loving memory of Luola Murchison Sprunt, wife of James Sprunt, of Wilmington and Orton, who departed this mortal life February 17, 1916, in the full assurance of a blessed immortality.

Of dignified, queenly presence, a mind richly endowed with exquisite taste and surpassing ability, she illustrated with unaffected modesty, as an angel of the highway on the journey of life, the virtues and graces of a noble Christian character, by an unceasing and untiring devotion to the things that are true, and honorable, and just, and lovely, and of good report.

Whatever she did for the rescue of human souls drifting away from God, for the conversion of the heathen in far-away lands, for the help and countenance of our devoted missionaries, for the care and education of the factory children, for the relief of helpless 
humanity in the hospitals at home and beyond, for the comfort of the bereaved and afflicted, for the lonely stranger in a strange land, in the building of churches, and hospitals, and schools, and habitations for the poor, in the skillful embellishment of her beautiful home, in her exquisite handiwork, in the promotion of patriotic and social endeavor for the betterment of our people, in her loving loyalty to her family and friends, in her winning endearment for children, in her uncomplaining endurance of suffering, in the divine majesty of a mother's love, in all things that were worth while, she did with her whole heart and mind and strength, with never an idle, misspent moment, with an eye single to the glory of God.

"The only visible link between this life and the next and the only work of our hands that does span the grave and follow us into the unseen world beyond is what we accomplish in endeavoring to imitate Him who went about doing good. Doing good is unselfishness in action; it is work for others, and its field comprehends the smallest kindnesses of every-day life as clearly as the noblest exercise of public charity. The cup of cold water marks it, as well as the church, the asylum, or the hospital, or the college. The loving smile, the cheering word, in this service may be more worthy of remembrance than all the world calls great outside of it." 
Dearly beloved and deeply lamented by hundreds of relatives and friends at home and abroad, mourned by her surviving husband and son and grandson deeply bereaved, but welcomed to glory by three devoted daughters who preceded her, a family divided between heaven and earth will, in God's own time, be reunited in a joyful resurrection.

"Seeing the King in His beauty, she said: 'Lord, here am I and the children Thou gavest me.'" "And I heard a voice from heaven saying, Write, Blessed are the dead which die in the Lord from henceforth: Yea, saith the Spirit, that they may rest from their labors, and their works do follow them."

-James Sprunt.

"Father, I will that they also, whom Thou hast given $\mathrm{Me}$, be with Me where I am."

O Death, why dost thou touch the tree beneath whose spreading branches weariness hath rest? Why dost thou snatch away the excellent of the earth, in whom is all our delight? If thou must use thy axe, use it upon the trees which yield no fruit; thou mightest be thanked then. But why wilt thou fell the goodly cedars of Lebanon? O, stay thine axe and spare the righteous. But no, it must not be; death smites the godliest of our friends; the most generous, the most 
prayerful, the most holy, the most devoted must die. And why? It is Jesus' prevailing prayer, "Father, I will that they also, whom Thou hast given $\mathrm{Me}$, be with $\mathrm{Me}$ where I am." It is that which bears them on eagles' wings to heaven. Every time a believer mounts from this earth to Paradise it is an answer to Christ's prayer. A good old divine remarks, "Many times Jesus and His people pull against one another in prayer. You bend your knee in prayer and say, 'Father, I will that Thy saints be with me where I am'; Christ says, 'Father, I will that they also, whom Thou hast given $\mathrm{Me}$, be with Me where I am.'" Thus the disciple is at cross purposes with his Lord. The soul cannot be in both places: the beloved one cannot be with Christ and with you, too. Now, which pleader shall win the day? If you had your choice, if the King should step from His throne and say, "Here are two supplicants praying in opposition to one another; which shall be answered?" Oh! I am sure, though it were agony, you would start from your feet and say, "Jesus, not my will, but Thine be done." You would give up your prayer for your loved one's sake if you could realize the thought that Christ is praying in the opposite direction-"Father, I will that they also, whom Thou hast given $\mathrm{Me}$, be with Me where I am." Lord, Thou shalt have them. By faith we let them go.

-Spurgeon. 
He who has watched the sun in its bright course through the firmament and seen it gradually decline until it went down in darkness beneath the horizon may turn from the contemplation with no feelings of sorrow or regret, for he knows that the period of its absence is mercifully ordained as a season of necessary repose to him and to all, and that the morrow will restore its beams to revive and reanimate all nature. But if the last declining ray which struck upon his eyelids had brought to him the conviction that he had gazed for the last time upon the sun in the heaven; that henceforward there was to be no more rising nor setting, no morning nor evening, nor light, nor heat, no effulgent day, with all its glorious beauties and excellencies, but night and darkness, unrelieved save by the twinkling stars, were to be the law of earth forever-with what sensations would the poor wanderer view that last setting of the sun?

With feelings somewhat akin to those I have imagined we behold the death of the great and good whom we love and reverence. But now they were here with all the generous impulses and excelling virtues that dignify and adorn humanity clustering thickly around them. We rejoiced in their presence, we were better under their benignant influence, we were happy in their smiles; we felt that it was day and looked not into the future. They are gone. The places of earth shall know 
them no more forever. The mysterious law which loosens the silver cord and breaks the pitcher at the fountain penetrates the heart. -George Davis.

\section{Heaben}

Life changes all our thoughts of heaven;

At first we think of streets of gold,

Of gates of pearl and dazzling light;

Of shining wings and robes of white, And things all strange to mortal sight.

But in the afterward of years

It is a more familiar place,

A home unhurt by sighs or tears,

Where waiteth many a well-known face.

With passing months it comes more near.

It grows more real day by day,

Not strange or cold, but very dear-

The glad home land not far away,

Where none are sick or poor or lone,

The place where we will find our own.

And as we think of all we knew

Who there have met to part no more,

Our longing hearts desire home, too, With all the strife and trouble o'er.

-Robert Browning.

\section{The ligme af fer fathergi}

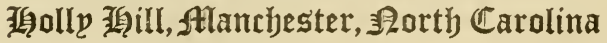

Her passing away brought sorrow to many hearts, and the sense of bereavement does not lessen as the weeks go by.

In this home of her grandparents and the boyhood home of her father all surroundings 


$$
\text { dी }
$$




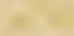

$+2$

$+4$

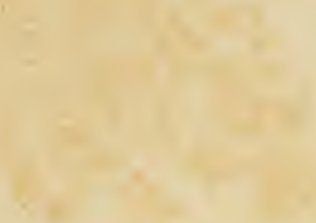

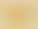

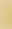

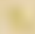

(n)

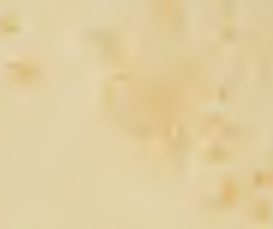

(1)

.

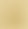


suggest cherished memories of her, and many familiar spots recall special and tender associations. The greatness of mind and heart that developed into a gracious womanhood and made her life a blessing to her family, her friends, the church, and the world were clearly marked in childhood. Her fine intuitions, her keen intelligence, her enthusiasm, her ability to enter into the feelings of others, and ever-ready helpfulness invested her personality with a charm as beautiful as it was rare. Many hearts were cheered by her sympathetic interest and many lives enriched by her generous affection. Richly endowed mentally, spiritually, and materially, she lavishly gave her best to the world, and the best came back to her in the love and grateful appreciation of her noble achievements. The light that shone on her pathway through life grew brighter and more serene to its gentle close.

She has passed within the veil and is "made perfect in holiness" and happiness. To us who remain her life on earth will ever be an inspiration and a priceless treasure.

-Lucy Gillespie Murchison.

\section{Birlhovi}

"Youth and its thousand dreams were ours."

Youth is a vision and a prophecy. The years from twelve to twenty would seem the 
golden years, as to vision. The foundation of character which these years establish is the basis upon which the future is to build. And if the building is high and noble it is good to look back and feel that the vision is true and the foundation sure.

\section{"Then age approves of youth And death completes the same."}

The Borough of Brooklyn, forming part of the Greater New York of today, is a very different place from the Brooklyn of I87I to I 879. During those years New York beckoned with alluring hand to many of the foremost men of the South and seemed to them the most fertile field in which to retrieve their fallen fortunes. Brooklyn had many advantages as a home for their families. Its convenience to New York, the family life it encouraged, its nearness to the seacoast, and the many economical conditions combined to provide an ideal place of residence.

Thus it was that the father of Luola Murchison came to New York and, naturally, after considering the reasons given, Brooklyn was selected as the place for the new home. These same reasons prevailing with the father of the writer, the two homes were established so near each other as to be almost within hail, and in this way promoted daily companionship. 
Looking back to that vision, it would be difficult indeed to find a happier girlhood than ours was, or a girlhood coming from dearer homes. At the head of the one was the energetic, successful, honorable business man, and of the other the high-toned scholar, editor, publisher, and the beauty, intelligence, and Christian virtues of the mothers in those two households are a famous heritage to their children.

It was from Brooklyn, then, that Luola was to draw her vision, and on this vision she builded a foundation which all through the years to come she could look back upon and thank her God that the foundation she had laid would last not only through the years of her earthly pilgrimage, but into all eternity. That she builded with no uncertain hand; that her vision was broad and comprehending, and that a beautiful gentleness was there, the pages of this book bearing loving appreciation of the many who came in touch with her after years will attest. And she-as the years grew and time filled her life with the keener joys and deeper sorrows of womanhood-she looked back and rejoiced because of the sweetness and the strength which she had gathered in those happy girlhood days.

She is always present to me as on that day when first we met. A girl of twelve years, with brown hair curling over her brow, and beneath these curls were wonderful, far-seeing 
eyes, which seemed always to be seeking for truth. Looking into those eyes, you felt sure of the beautiful soul from which they shone. Her every motion was graceful and conveyed an impression of the lovely things in lifeof music, youth, springtime, and flowers. Thinking of her as she appeared that day, girlhood is ours again, and she is speaking her sweet thoughts, her unselfish plans for others, her noble aspirations. Ah! what a pleasure it was four years ago to write and tell her that she had fulfilled them, every one.

I never see two young girls whispering their sweet confidences together but what she comes before my willing fancy. Never do I see children happy at their play but that her image is there. Thus does she send abroad an influence and multiply portraits of herself.

Nor was that girlhood purposeless. There was work worth doing and worth trying to do well. Duties were ever present and were a never-ending education of a fine sort. They were made easy by happy, simple, and congenial recreations. The gifts with which by nature she was richly endowed during these sunny days by concentration and perseverance she steadily developed. As a musician her work was highly valued, and her sweet voice contributed much to the happiness of her home. Her sentiment for nature was genuine; she embellished her own and other homes with touches of her art. In every 
variety of needlework her fingers were deft and the specimens that came from her hands were rare and beautiful. She enjoyed her art by using these talents largely for others. There comes no remembrance that she ever worked for self, although her activity was indefatigable. Rather was hers a nature that gave from its fullness.

Even in those early years her distinguishing trait was the love she gave little children. She was their friend and they knew it. She was especially beloved by the children in her own kinship, but not only upon these children was her affection lavished, but it was freely given to those in other households with whom she came in contact. May it not have been the Divine in her nature; the answer from her soul to the Master's "Suffer little children to come unto Me," which in the last year of earthly life pleased her Heavenly Father to place a motherless little one in those tender arms.

In her last letter was revived her loving recollection of the pets which shared our heartsome young life.

A very precious friend of this girlhood was Moses, I, uola's beautiful pony, and with the pony a basket phaeton came, both gifts from her father. The phaeton was just large enough for two, and there could hardly have been a part of Brooklyn that did not welcome the sight of Moses and the two girls in the phaeton, for- 
"The paths by which we twain did go,

Which led by tracts that pleased us well;

Thro' those sweet years arose and fell

From flower to flower, from snow to snow."

Three weeks before her death she writes: "How happy we were with my beautiful pony, the like of which I have never seen since. There will come a time when we shall be together for eternity, when the friendship of our girlhood days will mature into joy everlasting."

In May, I883, she writes of her approaching marriage; her heart is overflowing with love and admiration for and confidence in the man she has chosen for her life's companion. "With him near me, I feel I can lead a higher, better life than I ever hoped for."

Girlhood does not go with her into that life where, blessed with the love of husband and children, she grows in good works.

And now that she is looking back to the vision and beholding the foundation and seeing that it was good, she exclaims, "Thanks be to God which giveth us the victory through our Lord Jesus Christ." Amen.

"So, dearest, now thy brows are cold,

I see thee what thou art, and know

Thy likeness to the wise below,

Thy kindred with the great of old.

"But there is more than I can see,

And what I see I leave unsaid,

Nor speak it, knowing Death has made

His darkness beautiful with thee."

I 6 -Ellen Hale Wilson. 


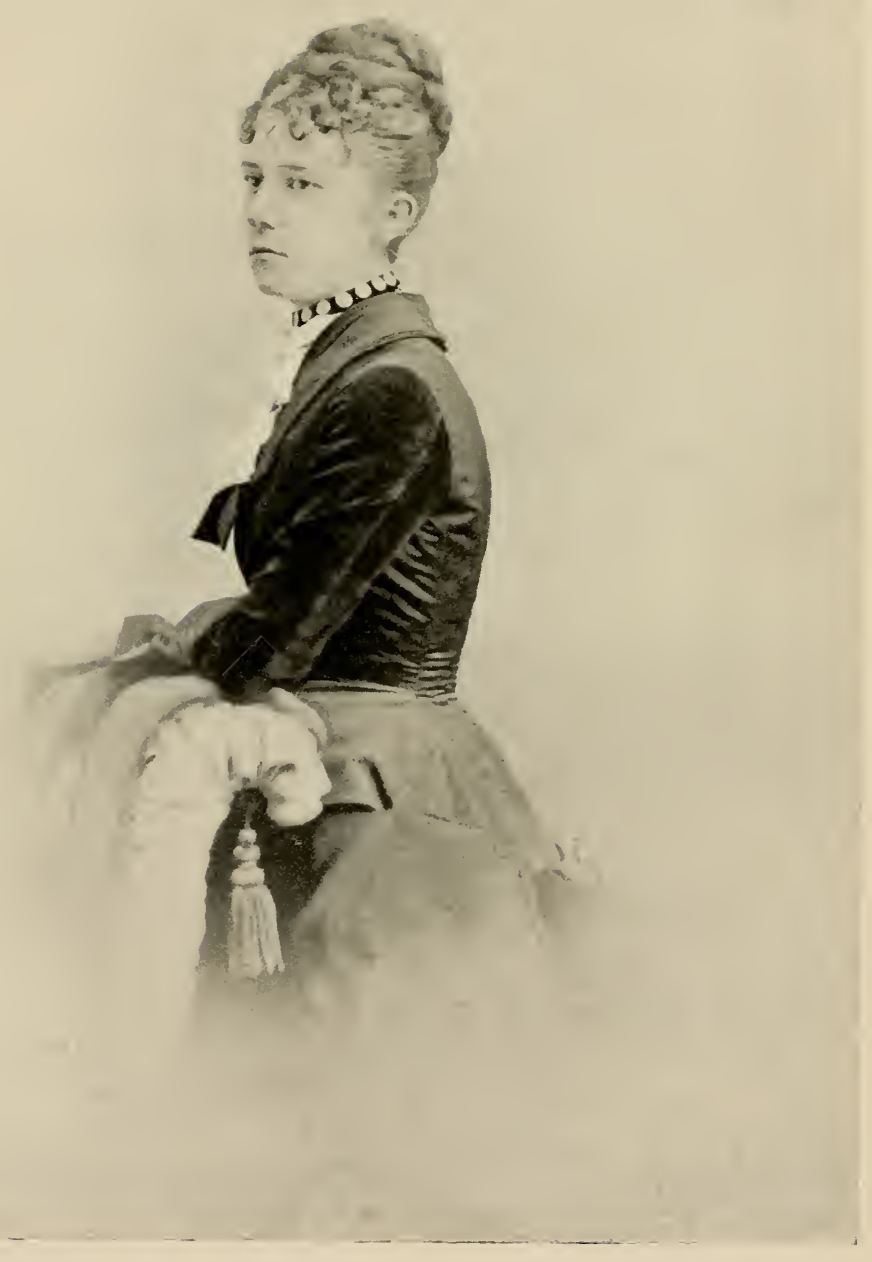

LUOLA, AS A SCHOOL GIRL 



\section{Homeg}

"Flowers of all hue, and without thorn the rose."

She who was so tenderly loved and universally admired, Luola Murchison Sprunt, has passed to the great beyond, and many there are who mourn for her.

Of singular grace and warm sympathy, she endeared herself to all who came in contact with her, and the extent of her influence for good is well-nigh boundless.

She was endowed with many talents, conspicuous among which was her artistic ability. This expressed itself in many ways, notably in the beautiful appointments of her home in Wilmington and Orton.

Her friends remember her keen enthusiasm for the rare and exquisite etchings, of which she made a most interesting collection, and love to think of her as she explained the excellent work of her favorite artists.

Amidst the many changes of the years, how great is the pleasure of reviewing happy hours of the past. "Yes, tho' thy smile be lost to sight, to memory thou art dear." How handsome and gracious was Mrs. Sprunt that day when she welcomed as her guest in her Wilmington home President William H. Taft. The occasion was a formal breakfast in honor of the President and a party of friends. No setting for such a scene could have been more charming. The vine-embowered piazza with 
its outlook on a fair garden, the graciousness of the accomplished hostess-all presented a picture long to be remembered.

Again, how dear to her friends is the recollection of Mrs. Sprunt in her rose garden, her arms full of the lovely blossoms she was gathering for her visitors. Among these memories, first and foremost must stand the picture of Orton, where the fairy-like touch of the lovely owner had made the historic old plantation a scene of unique beauty. How truly gracious and sweet she was to her guests at this most hospitable Southern estate!

Nothing, it would seem, so delighted her loving heart as giving comfort and pleasure to others. She responded immediately to the suffering and needy, whose wants she so unostentatiously relieved, and her messages of sympathy for her friends in sorrow, so affectionate and consoling, gave utterance to thoughts of great beauty, reflecting as they did the blessed truths of her Lord and Master Jesus Christ.

Mrs. Sprunt's impulses were wonderfully kind and strikingly effective, springing as they did from the warmest and most generous of hearts, the echo of her own deep spirituality.

She gave of herself in the most enthusiastic manner, whether in the gift of a beautiful bouquet of her Orton hyacinths or in the erection of a hospital for suffering little children, for all time. 
Only those nearest to her in her confidence could have any idea of the number and variety of her beneficent deeds.

Such a spirit as that of Luola M. Sprunt can never die. Her life here will be an example and inspiration for those who are left to mourn her loss, and time will not dim the beauty of her sweet, strong personality.

"The reason firm, the temperate will, Endurance, foresight, strength and skill;

A perfect woman, nobly planned, To warn, to comfort and command."

-Lucile Wright Murchison.

"She lingers there like sunshine over the ground, And ever I see her soft white fingers searching after the bud she found."

We sometimes playfully called our dear one the "Stormy Petrel" because of her almost unceasing activity, but even that wanderer upon the wide ocean finds rest upon the heaving bosom of the sea, and when her physical power waned and the headache warning must be heeded, she ever turned with thankfulness to our country home, fourteen miles down the river, which brought relief and steadiness to her overwrought nerves.

We linger at Orton, the most attractive of all the old colonial estates on the Cape Fear. For a hundred and ninety-one years it has survived the vicissitudes of war, pestilence, and 
famine, and it still maintains its reputation of colonial days for a refined and generous hospitality. Here, in the exhilaration of the hunter, the restful seclusion of the angler, the quiet quest of the naturalist, the peaceful contemplation of the student, is found surcease from the vanities and vexations of urban life. For nearly two centuries it has been a haven of rest and recreation to its favored guests.

"Here, like the hush of evening calm on hearts opprest, In silence falls the healing balm of quiet rest;

And softly from the shadows deep

The grand oaks sing the soul to sleep On Nature's breast."

The house, or hall, built by "King" Roger Moore in 1725 , with its stately white pillars gleaming in the sunshine through the surrounding forest, is a most pleasing vista to the passing mariner. The river view, stretching for ten miles southward and eastward, includes "Big Sugar Loaf," Fort Anderson, Fort Buchanan, and Fort Fisher.

We loved its traditions and its memories, for no sorrow came to us there. The primeval forest, with its dense undergrowth of dogwood blossoms, which shine with the brightness of the falling snow; the thickets of Cherokee roses, which surpass the most beautiful of other regions; the brilliant carpet of wild azaleas, the golden splendor of the yellow jasmine, the modest drosera, the mar- 
velous Dionaea muscipula, and the trumpet sarracenias; the river drive to the white beach, from which are seen the distant breakers; the secluded spot in the wilderness commanding a wide view of an exquisite landscape, where, safe from intrusion, we sat upon a sheltered seat beneath the giant pines and heard the faint "yo ho" of the sailor outward bound; a place apart for holy contemplation when the day is far spent, where the overhanging branches cast the shadow of a cross, and where later, through the interlacing foliage, the star of hope is shining; the joyful reception at the big house, the spacious hall, with its ample hearth and blazing oak logs; around it, after the bountiful evening meal, the old songs sung and the old tales told and fun and frolic to keep dull care beyond the threshold.

But even at Orton she found her rest and recreation in restoring and beautifying the old place, which responded to every touch of her magic hand, because she was ever in harmony with nature and with art, and the old and the new were blended into a perfect colonial home.

Her care of old St. Philip's Church ruins on this plantation arrested its decay and made this venerable pile the mecca of the yearly pilgrimage of the Colonial Dames. Contrasting its roofless walls with the need of modern times, she builded near the dwelling-house a beautiful chapel of pure colonial design by 
her brother, an eminent New York architect, for the use of our guests and for the neighborhood white people, for there was no other church for miles around. It seats 100 persons and it is not yet dedicated, but it will ever be known as "Luola's Chapel."

Her last gift was another beautiful church for the colored people of Orton and their friends, which seats I I persons. This was recently filled on its dedication to the worship and glory of God by the celebrated evangelist, Rev. Dr. J. Wilbur Chapman, who with his party were guests at Orton. The scene of this beautiful service, which touched the hearts of all present, will live in their memory as long as life lasts. In solemnly dedicating the gift of one of His saints who had recently been called to the "house not made with hands," the eloquent preacher earnestly admonished those present to take heed lest they defile by sinful thoughts this sacred building; and, said he, "The dedication of this church cannot be complete unless you also dedicate yourselves to the Master's service." Immediately, as by a common impulse, every colored person present came forward and kneeled in a semicircle before the minister and solemnly took the vow of allegiance to the King of Saints. The gentle spirit of the giver seemed to abide with us that day. 


\section{Irecollectiong}

"Eternal sunshine of the spotless mind."

Luola Murchison married my uncle, James Sprunt, in 1883 . My earliest recollection of her pictures a very sprightly, cordial, and sympathetic person, who always knew what was the matter when anything went wrong, and how to set it right. Today recalling her as I saw her the last time, just a few weeks ago, the words of the greatest eulogy in our language come to me: "She was my friend, faithful and just to me." For more than twenty-five years her friendship never for a moment faltered-never once lost an opportunity to perform some gentle service.

Very precious to me is the following page in my childhood, very dear to me because I love to think how closely she was knit into the warp and woof of our earliest years. My brothers and I were still quite little when our parents were called North and we were left with Aunt Luola, who adopted us and a fairy world opened up before us. She took us to Masonboro Sound and cared for us with a devotion and tact that $I$ now recall as most extraordinary. I admired her so much that I felt I should like to acquire that power which even as a child I felt she possessed. On one occasion we were speaking of beginning things and throwing them aside unfinished. I do not know whether she intended 
it for a hint or not-my propensity for discarding tiresome tasks was rather well known in the family - at any rate, she told me that in her impulsiveness she often used to throw a thing aside to start something fresh, and her mother gathered together all such attempts and quietly put them in a drawer and one day said to her, "You may not begin anything else until you finish all these bits of fancy work that you have started." Aunt Luola said she wept much over the task, but she learned her lesson. Never again did she let any bit of work leave her hands unfinished. That taught me also a lesson---never to abandon a purpose until it has been accomplished.

My aunt possessed a wonderful power. It was something more than personality; it was what Emerson alludes to as a sense of mass and defines as character, naming its chief manifestation self-sufficingness. My own attitude toward her reminds me again of Emerson's eulogy, "I revere her who is riches; so that I cannot think of her as alone or poor or exiled or unhappy or a client, but a perpetual patron, benefactor, beatified woman." Such qualities as furnished her especial genius might have been embodied in a great reformer or a statesman or a general, but in her they blended into one great simple expression, and with Abou Ben Adhem she might have said, "Write me as one who loves his fellow-men." 
Wealth was a mere incident. I believe if she had been a daughter of toil her thoughts for others would have been just the same. $\mathrm{Her}$ ingenuity was amazing. She never despised little things nor failed to make use of every advantage the occasion offered for helping rich and poor alike. Her power of discernment was so great that when applied to a business problem it divided unerringly the false from the true; and yet this same judgment was available for any one in any emergency and took the very facts of the case and solved the difficulty in its own environment; for her sympathy made it possible for her to understand the poorest woman in her hovel and yet to comprehend the most complex motives of the most subtle action.

All the experiences of her life seemed to contribute to the strength of her character. There was something almost heroic in her grief. But in proportion to her sorrow was her ability to sympathize with the heartbroken. One of her greatest activities was writing words of comfort to mourning hearts. In the sleepless hours of the night, when pain made it impossible for her to rest, her thoughts turned to the sad and suffering, and out of her own full heart she sent a message of cheer.

There never seemed any emergency too difficult for her to meet, a situation too delicate for her to handle. Her tact and cour- 
tesy enabled her to achieve the most remarkable results. During the term of years when she was president of the North Carolina Society of Colonial Dames of America she pursued a policy which attracted the attention of the foremost national members and won for the society an enviable reputation. Possessing a very keen mind and one capable of discerning ability in others, she encouraged all mental effort and set in operation valuable research work which has been of the greatest benefit to the State at large.

In conversation she was most versatile. One found intellectual people turning naturally to her, and her wide and varied experience gave an authority to her opinion on all subjects.

Her loyalty to her family and her devotion to each member of it was as beautiful as it was intense. She held them together by her very love for them and her unstinted appreciation.

Her personal pleasures were few, or, to be more exact, she found her pleasure in making others happy. Her charity was so broad that she found good in every one and realized the difficulties and temptations of every soul. Her character possessed in fact a symmetry that one could not fail to perceive and appreciate. Her love of justice and sincerity was as pronounced as her charity and generosity, and to the day of her death she clung fast to 


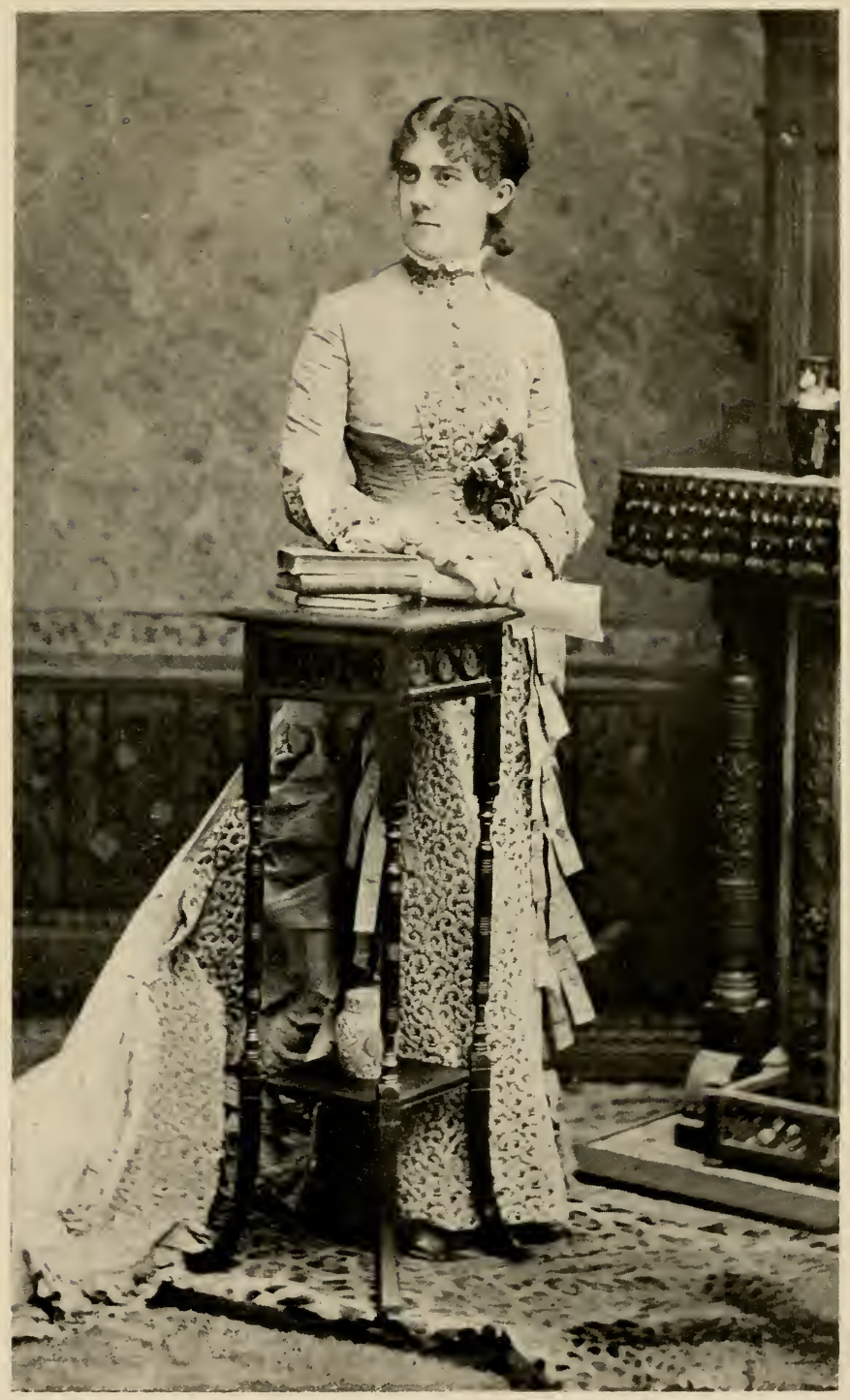

LUOLA MURCHISON, AT THE AGE OF 20 YEARS 

her lifelong habit of bearing the burdens of others, of glorifying God in her body, which was His, and which she confidently expected would bear the image of the heavenly even as it had borne the image of the earthly.

\section{-Jeanie Dalziel Wood.}

"Fold her, Oh Father! in Thine arms, And let her henceforth be

A messenger of love between

Our hearts and Thee."

I have come to the conclusion, remembering all I can of her remarkable personality and wonderful life, that she was, like my mother, one of those "women who ministered to Him." How different they were, those two, and yet how alike in purpose. To each of them belongs every word of Solomon's inspired description of the wise woman. Each of them, while she strived for the noblest and gentlest virtues of the woman of yesterday, devoted to her home and family, conservative and domestic, had caught the farthest vision and entered into the highest tasks of the woman of today, who is a gracious elder sister to all the world. Do you remember how Aunt Luola thought of that unique plan of sending hundreds of yards of cloth, with needles and thread and patterns, even, to the Belgian women, who were without 
clothes and without work, long before the Relief Committee suggested the selfsame plan? Some one who came to Wilmington about that time was so thrilled at the wonderful thoughtfulness of her generosity that she said, "What a woman! Every time I come back to Wilmington I hear of some great new charity of hers." "First she gave herself." This I think explains all her giving, her personal sympathy and appreciation of others' needs. Then her appreciation of others' lives and character was most sincere, and she gave her praise with as ardent a spirit as she gave her help. Her deep and adoring love for my mother is one of our very most precious memories. I often think that in the affectionate letters she wrote mother, she was writing unknowingly the very things we who love them both feel and say of herself. "Sweetest sister," she loved to call mother, which was the title her own sisters had given her.

And another proof of her great and generous spirit was her appreciation of the services done her by those who loved her, from her own beloved family to the humblest servant. You remember how she said to Lucy, the cook at Orton, during a time when things were temporarily disorganized in the kitchen, "Oh, Lucy, you are so good to me; I think you are a real Christian to work away so patiently with a stove no bigger than a pockethandkerchief." Poor grateful Lucy could 
only assure her that no service was too much to render such a mistress. She has often said that "she was made for emergencies," and we all knew her ingenuity, her swift grasp of a situation, and her generalship in organizing and using her resources. But the truth is, she was made for service; no matter how difficult, how delicate, how exacting a task, she had the will and the spirit to do it well. Few people I ever knew have been so variously and lavishly endowed by nature. Her fingers were as nimble as her brain, and that is to say much, for the play of her thought was swift as the wind that sweeps over the wheat. Once when Laurence was studying with me, he said: "Cousin Sue, I just couldn't work last night; mama had a guest and I had to listen-you know how mama can talk." Indeed I know-blessed be her tongue forever. How she made me laugh in the midst of my own gloom, even when she was lying helpless herself and in pain; how she rose in the early dawn to take her ready pen and pour her balm into some lonely and suffering heart, when she was a constant sufferer herself. Thank God for the friendship of such a spirit, for the prospect of eternal association with her in the "land that is very far off."

But, even if we could speak, all we feel, as we cannot possibly, the sum of it is just that she "ministered unto Him." Her life 
with God was the source of all her beauty. "It is the spirit that quickeneth." Forever and forever her glorified spirit shall continue the work of love so graciously begun here. No dark grave is the home of that bright spirit. And thus only can we find relief from the desolate loneliness and longing of the bodily separation.

-Susan Eliza Hall.

\section{Friendihip}

"Friendship above all ties does bind the heart."

A Tribute from One Who Knew and Loved Her from Early Girlhood and to Whom She Gave the Friendship of a Lifetime.

Her name is a synonym for all which stands for high ideals, lofty aims, and deep religious fervor. Faithful to every duty, her guiding principle was "loving and serving the highest and best." Of love and friendship, and help that sprang spontaneously to meet all needs, she gave unsparingly. Her warm loving heart was ever reaching out to soften and relieve all misery and suffering, to smooth the rough places in life's pathway and strengthen and encourage the sick and hopeless. Her bright, buoyant spirit touched and vitalized all circles in which she moved. Gifted by nature with boundless energy, versatile talents, and a mind ever ready to grasp and control all conditions and emergencies, obstacles 
to her were only stimulants to greater effort; but, modest and self-depreciating, she claimed for herself no honor for any triumph won. Endowed with artistic tastes and temperament and a high appreciation of all that is fine and beautiful, she also possessed a brain so strong, so vigorous and forceful, that one instinctively turned to her for advice and guidance along all the practical lines of life. Not one of her many talents was allowed to rust for lack of use. The seven years she was President of the North Carolina Society of Colonial Dames stand out prominently in the history of the society. Her marked executive ability greatly broadened the scope of its work and strengthened its place in the National Society. Can those of us who were privileged to serve under her administration ever forget her? To remember her as a presiding officer is to recall her graceful poise, her natural ease and dignity, her gracious courtesy and never-failing kindly tact, a combination rare indeed, which won for her the loyal love of a large and varied organization.

If the measure of life is the well spending of it and not the length of years, then hers indeed was a long one; but, called at last to higher service in the great beyond,

"Oh, blessed consolation in our grief to feel

There is no death; whatever seems so is transition;

This life of mortal breath is but a suburb of a life Elysian Whose portal we call death."

-Florence Hill Kidder. 


\section{Tributeg from}

We have known some such women as this Phœbe of whom the apostle writes in Romans I6: I, 2, 3. One such entered into rest only last week, after weeks of patient trust in God, closing a life of rare excellence and full of good deeds. She had done all from her throne in her home and the heart of her husband. From the home rather than from the church, to which she was loyal, her body was borne to its last earthly resting place. She was like Phœbe-a "sister" to all the family of our Father as related to His Son, our Elder Brother. She was "servant of the church," not ostentatiously, but in ways most wise and helpful, to many individuals and to the cause of Christ in "the regions beyond." She was a "succorer of many" in unstinted hospitality and timely help. This entire city mourns her loss, and the high and low, the poor and the rich are telling of the many-sided ministry to others. With others we thank God for her life ministry of mercy amongst us.

-A. D. McClure.

"But the fruit of the Spirit is love, joy, peace, longsuffering, gentleness, goodness, faith."

She never forgot a friend. Of all her many gracious and lovely traits I believe this was, perhaps, the most characteristic.

There can be no greater or truer virtue than this, for "Greater love hath no one than 
this-that one lay down his life for a friend." She was always laying down her own affairs and setting aside her own plans, forgetting her own sufferings for the sake of others. It never seemed as though she were conferring a favor, for she had the unusual faculty of making the pleasure and comfort of others seem her own.

Every one of those delightful visits to Orton stands out distinctly in my memory, but as I write one occasion recalls itself more vividly than the others. It was my first visit to Wilmington after I had moved to Chapel Hill. The invitation from both of you awaited me on my arrival. I accepted, of course; indeed, I don't think I ever declined a single one of those invitations.

I went to the wharf and there found the most bountiful and delicious provisions, put up by her own hand. I thanked Link, the butler, and was about to say good-bye to him, when he told me that Mrs. Sprunt had instructed him to go down the river with me and take good care of me. A severe headache had prevented her from making the trip, but it had not prevented her from taking every forethought and making every arrangement for my comfort and pleasure, to the smallest detail.

God has been very good in the friends $\mathrm{He}$ has given me, and for the friendship of your wonderfully kind and generous wife I thank 
Him from my heart. I still have and shall always keep the lovely fur coat that she brought me from one of her trips to New York.

Have you ever thought of the multitude who have gone into the "other life" without having known great joy and real friendship here-many without the knowledge of the Saviour? I know that God ministers to these through just such ones as your dear wife, and that she must be doing a wonderful work now for those who on earth never knew such a personality as hers. And how happy she must be in her work without the pain and limitations of the "natural body."

I hope that you will realize more and more that her prayers and her spirit are with you and will be with you until the end.

"When earth's last picture is painted And the tubes are twisted and dried;

When the oldest colors have faded

And the youngest critic has died, We shall rest, and faith, we shall need it,

Lie down for an æon or two,

Till the Master of all good workmen

Shall call us to work anew.

"And only the Master shall praise us, And only the Master shall blame;

And no one shall work for money, And no one shall work for fame;

But each for the joy of the working,

And each in his separate star

Shall draw the thing as he sees it

For the God of things as they are." 


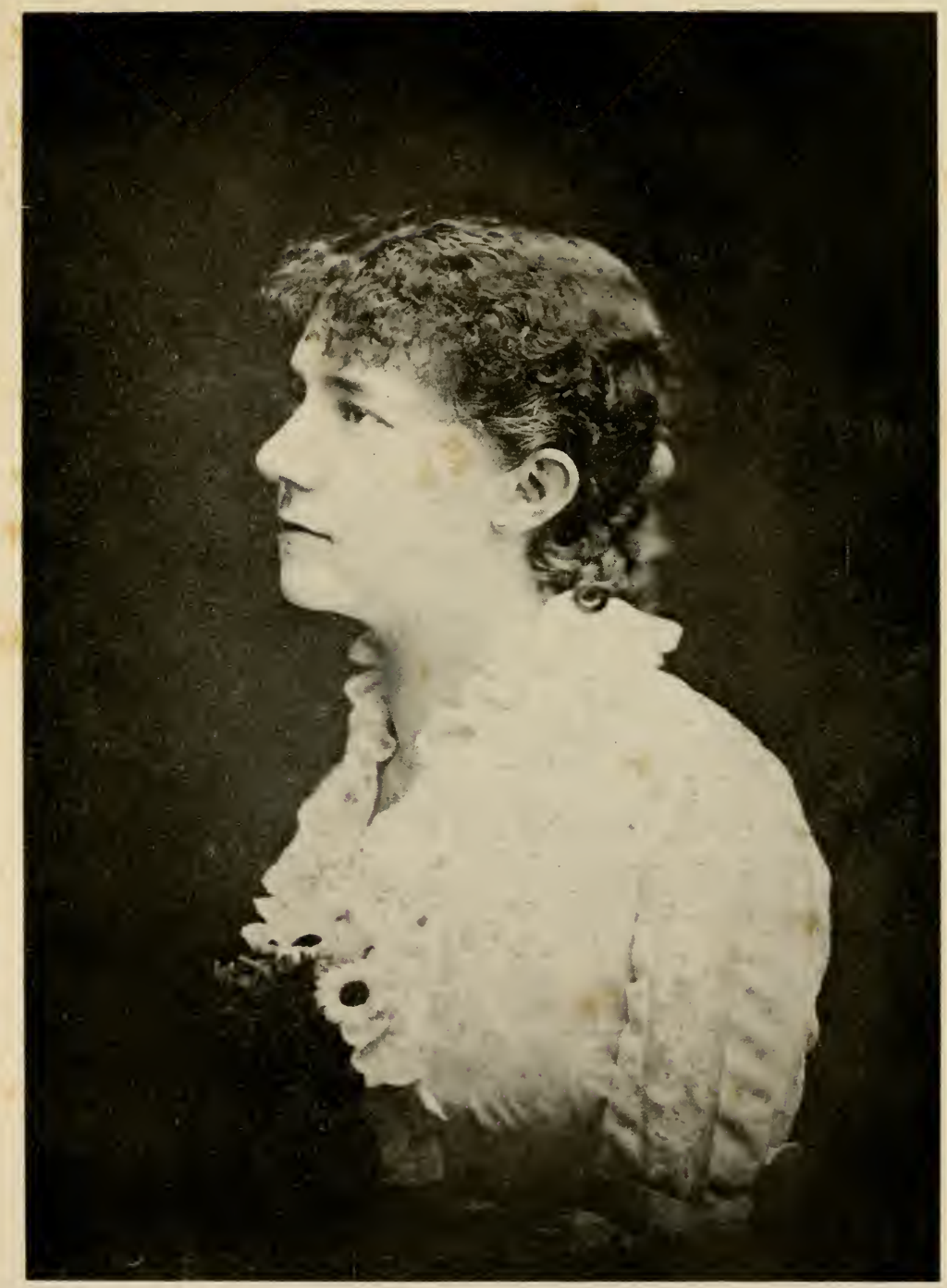

LUOLA MURCHISON, A FEW MONTHS BEFORE HER MARRIAGE 

What I have said out of my heart about your dear wife I feel about you, for you were as one in your loving kindness and generous friendship to me. I came very near being in Wilmington this week on a mission in behalf of Sewanee, and one of the things I had counted on most was seeing you and perhaps Orton.

May God be with you always is the prayer of your devoted friend,

Richard W. Hogue.

\section{Appreciationg}

"For all the saints who from their labors rest, Who Thee by faith before the world confessed, Thy name, $\mathrm{O}$, Jesus, be forever blest. Alleluia."

In the providence of God a useful and what seemed to be necessary life has been cut short and the community in which she lived has lost a beloved and valuable citizen in the death of Mrs. Luola Murchison Sprunt.

Her beautiful and unusual character is so deserving of mention that this hand of affection wishes to pay a slight tribute to her memory and to record some of the virtues that won the admiration of intimate friends and endeared her to all who knew her.

Upright, honorable, strong in her convictions of right, kind of heart, and ever ready 
to help, she will be sorely missed in many a household. Always taking a keen interest in all that concerned those about her, she was quick and ready to respond to any appeal for aid and sympathy.

It was in her home life, however, that her light shone brightest, in the dispensing of a lovely, gracious hospitality, which was generously bestowed upon the rich and poor alike. Especially was this so at her beautiful country home, Orton, where many a grateful heart will recall the return to health and happiness gained by a visit to this delightful place. There was no sphere or circumstance of life in which Mrs. Sprunt was placed that she did not fill with great dignity and efficiency; but the beautiful spirit of hospitality was perfectly exemplified in her desire to share her blessings with those who were near, as well as the "stranger within her gates," many of whom were strengthened and encouraged for the battle of life, stimulated by this noble woman and her lofty ideals.

It was manifest to those whose privilege it was to be with her during the last months of her illness that she bore her suffering with wonderful patience and Christian fortitude, always more thoughtful of those around her than of her own suffering. We love to think of her now with her Saviour, whom she loved so loyally, free from sorrow and pain, surrounded by many of her loved ones and yet 
still busy in the service of her Master, ministering to those dear ones left behind, whose lives will ever feel her influence.

-Lucy Atkinson Murchison.

"But, lo! there breaks a yet more glorious day,

The saints triumphant rise in bright array;

The King of Glory passes on His way. Alleluia."

To the many beautiful things that have been said of Luola Murchison Sprunt may I add this tribute of love.

Mrs. Sprunt was endowed with rare gifts of mind and body; was generous, warmhearted, and brave. To her friends she was loyal and devoted, wise in counsel, strong of vision, fearless in speaking the truth, ever ready to share their joy or sorrow and giving them unreservedly of her influence, power, and of herself. As a leader Mrs. Sprunt was particularly fitted. Instantly grasping a situation, she infused her own efficiency and enthusiasm into her co-workers, stimulating thein and opening up new vistas of service. Shy, timid natures caught the inspiration and gave her their loving best. Even the weak and feeble felt there was still some work for them to do.

In her inner life Mrs. Sprunt was deeply religious. Believing implicitly in prayer, she lived daily under the direction of the Holy Spirit, with unfaltering trust in her Master, 
whom she delighted to serve. Abhorring inaction, every faculty of her heart, mind, and body was alert and busy reaching out in numberless avenues to all humanity with love, tenderness, sympathy, and kindness, ever watching lest an opportunity slip for righting some wrong, lifting some burden, brightening some life, relieving suffering, influencing towards higher things, helping the discouraged, the tempted, the weak, the sick, the sorrowing with a word, a flower, a letter, a prayer.

-Kate W. Fairley.

"Now there are diversities of gifts, but the same spirit."

The most unusual thoughtfulness of others was the dominant note of her life as I knew her. It was always a puzzle to discover how she could know so much of the needs, desires, ambitions, and good points of the many who were the recipients of her loving bounty. She could pick out gold in a rough, unlettered man with unerring precision and she never made a mistake. In that large number of her intimate friends who are today lamenting her loss can be found all sorts and conditions of men of all colors and creeds. A blacksmith, a street-car motorman, a street-cleaner, a fallen woman, a starving clergyman, a doctor, a foreign minister-all had shared in her discriminating kindness, for she knew just what each needed, whether it was a load of 
wood or a loaf of bread or a simple note of encouragement. In her latter months, when her failing strength kept her on her bed, she turned to wonderful use her splendid skill at note-writing, and there are many of these evidences of her love that are now treasured possession of the recipients.

When the need of a hospital for suffering women and helpless little ones was mentioned to her she immediately with her larger vision saw a chance to help not only these sufferers directly, but the whole community indirectly. She saw that the greater function of a hospital was as an educational institution, and she knew that if she could direct the efforts of all interested in the way of creating a place of instruction for the medical profession, the whole community would share the blessing of a greater efficiency. She knew, too, that a teaching hospital not only does more for the sufferer, but in turn the sufferer becomes a benefit to the whole community. She knew that her own case had proven of value to patients yet unborn because it had been studied in Johns Hopkins Hospital and the records carefully preserved. She had felt the contact with Dr. Osler's ideals in medicine enough to know that the patient rather than being experimented with to his torture or distress was being doubly benefited by the more searching investigation. Her weeks in the Baltimore hospital might be thought to have 
been wasted, for she was not greatly helped physically, but it seemed to me to have been the most fruitful period of her life, for she acquired in that short time with her brilliant intellectual grasp an idea of the true spirit of healing as it is known to the highest of the medical profession, and she brought it home to us and became our most helpful teacher. She had learned the function of a great hospital and she had seen how science and sympathy could go hand in hand with progress, and that, while she could not be cured, she was given the blessed privilege by her very sickness of lifting the load for countless patients yet to come.

It was a short step from this new point of view to its application in her home town. As a result of her sympathetic appreciation of the needs of the medical profession she was instrumental in having appointed the first visiting staff of the James Walker Memorial Hospital. This single movement would have justified an ordinary life, for the results of it can never be reckoned because of the never ending chain of good it is destined to bring about in the years to come.

The building now in process of construction on the grounds of the James Walker Memorial Hospital, a memorial to her little daughter, will show in many of its details something of her wonderful mind that could apply its power even to hospital architecture. 
Many of her suggestions will, no doubt, be copied by greater hospitals in the time to come, for her appreciation of the needs of the little patients was so intimate that the application to her was simple, indeed.

As her physician I saw her under every condition. Her capacity for uncomplaining suffering was unequaled in my experience and her bravery was the more striking because her intellectual appreciations of things generally told her with unerring precision just how serious each of her heart attacks really was, and it was impossible to deceive her. In the midst of it all she would inquire for each of my patients who were seriously sick, be it a poor negro or an intimate friend. It was no uncommon thing after a visit to her, when she would quiz me about some patient's needs, to find on my next visit that the ministering angel from her own bed of suffering had sent a messenger laden with delicacies of all sorts, but the greatest of these was the loving message accompanying it. I had received so much from her hands that I was constantly overwhelmed by it. Not the least of the blessings for which I have to thank her was the good advice which always proved unerring. Whether it was a professional matter or one of most personal nature, her advice was clear cut and precisc and never at fault.

Surely she being dead yet speaketh.

$$
4 \text { I -Edward Jenner Wood. }
$$


"and in her tongue is the law of kindness."

"When I met Cousin Luola two years ago in Paris, I was privileged to have a closer insight into her character than ever before. She spoke so frankly and expressed herself so sincerely, that I left her with a deep impression of what a fine woman she really was.

She told me of having persuaded you, at a time when business was not exactly flourishing, to make a tremendous sacrifice, for the Wilmington Y. M. C. A., when that excellent institution was in need of help to further some worthy project then in hand. Her description of you as a young man was an appeal put in such a way that it could never have fallen on deaf ears.

To do for others as we do for ourselves is so rare a quality in this selfish world, that it was an elevation in this ordinary commonplace life to have it exemplified in the simple and frank words, as expressed to me by Cousin Luola. I will never forget her words of wisdom and counsel to me on that occasion. Cousin Luola was one among thousands, aye hundreds of thousands. She has gone but her memory lives and her deeds are an inspiration to others. The lines composed by my Grandfather, engraved on the stone erected to Lord Houghton:

"Here fond remembrance reared the sculptured stone to one Who looked on mortal foibles with a sigh of tenderness And found his chief meed in thoughts of duty done." 
These lines more than any I can think of describe in appropriate language the beautiful character that has been taken from among us in the person of Cousin Luola.

-Dalziel Hedderwick.

\section{"Death is a translation into life." \\ "Those we call dead \\ Are brothers of an ampler day \\ For ever nobler ends."}

"All the gifts that were in her, penetrated as they were by spiritual significance, told of immortality. Such a presence as hers, erect and prophetic, was itself a pledge that its life cannot be spilt as water."

Once in a far-distant time God's messengers to man came in glistening white and, with the majesty of angelic function, delivered to those privileged to receive them the commands of the great I Am. Radiant moment! Marvelous privilege! Wonderful experience, this talking face to face with one of the heavenly host! But contact no more vital than is granted many now who live day by day and year by year in close association with spirits as truly the messengers of God as the white-winged multitude. Human as we, yet dwelling on sublimated heights; our companions and intimates, yet exalted above the incompleteness and the emptiness that mar the fast fleeting days with most of us. Such was Luola Murchison Sprunt. Hers was a life 
sent from God. If to any this seems a statement borrowed too nearly from the sacred Word, let them consider for a moment the fruits of her life, so in harmony with the requirements of the sacred Word. Now that the Lord, whose she was and whom she served, has called her to higher tasks, the results of her labors on earth are finding more fully the acknowledgment she endeavored while living to suppress. Here a letter from a factory superintendent, voicing the gratitude of himself and his employees for the education and care of the factory children; here a memorial service in China expressing the deep sense of loss in one whose arm of usefulness stretched in power across the seas to uplift and train the heathen; here letters from patriotic societies acknowledging her exceptional service in furthering their aims and in administering their affairs; here letters from church and charitable organizations telling of the enlargement given their efforts by her personal labors and liberality; here messages from an innumerable company to whom she furnished homes, clothed and fed, comforted and gave new hope. The intimate testimony of her friends and the acknowledgments from an extended acquaintance, from the highest to the lowliest, all are redolent with fragrant memories of her queenly bearing, her gracious personality, her deep spiritual discernment, her marvelous and fruitful service. Her 
activities were too numerous to be recorded, for hers was a life that "translated truth into conduct," and she constantly, though unconsciously, measured her life by the service she was able to render others. Treading this royal pathway, she ever traveled heavenward along the way her Saviour trod; and now that she has come to the end of that glorious way and the great white portals have opened to admit her to the presence of her Lord, marvelous will be the tasks $\mathrm{He}$ has reserved for a spirit so harmoniously related to heavenly requirements while on earth, and so richly prepared for more exalted labors in heaven. Sent from God and returned to God; but the memory of the sweetness and strength of her life, the beauty and depths of her character, the great scope and marvelous fertility of her service she has left as a gift in perpetuity to earth, and these shall bear fruit while time shall last. Not only the life, but the labors and influence of the saints are immortal.

-Samuel A'Court Ashe.

-Rosa Pendleton Chiles.

"O ye mountains and hills, bless ye the Lord."

She had such a magnificent capacity for enjoyment that I always thought of her in connection with those words of the late Charles Kingsley, "Nothing but God can satisfy a woman." Her heart was so large and her 
sympathies were so wide, she looked as if she could embrace the world, and I know that is how she felt. I think only one such woman may be born in a century, and one of her many attributes was that she caused herself to be appreciated in her lifetime. Her light was so bright that she could never pass unobserved. To me she was the axis on which the world revolved. We knew each other only by name until not much more than a dozen years ago, but from the first moment I felt at one with her. I never wondered why or questioned the fact; it was just there. All that she did was perfection in our eyes. What a happy time we had together that month of August when we went motoring to Inverness and through the Pass of Glencoe. She so loved the mountains. "Oh, those mountains!" That was what she exclaimed every few minutes. So you remember, or rather, can you ever forget?

-Tomina Dalziel Jackson.

"He that loveth his brother abideth in the light."

Some months ago a traveling circus company through stress of misfortune disbanded in Wilmington, and one of its employees, a young Spanish woman, a lion-tamer and yet a Christian, was left penniless. For several months she lived alone in a little tent on Wrightsville beach and gained a precarious 
living by palmistry. She never asked for help nor for sympathy, even when the tempest destroyed the fabric of her humble home, but "the radiance of a noble soul" discovered her sad plight and brought new hope into a discouraged heart.

"They were tempted, * * * they wandered about in sheepskins and goatskins, being destitute, afflicted, in deserts, in mountains, in dens, and in caves of the earth."

From a circus in a far-distant State the liontamer writes of her friend as follows:

She was a ministering angel in earthly form, graciously kind; to know her was to revere and love. I count myself greatiy blessed in that I was permitted for a brief space to enjoy her gentle presence and feel the radiance of her noble soul. All unworthy to her dear memory, I offer this humble tribute from one of the many whom her true Christianity benefited.

-Isola Daniel.

\section{Tributegi from colonial gameg}

"Consilio et prudentia."

In the death of Mrs. James Sprunt this community has suffered a loss the fuil extent of which will be revealed more and more with the passing of years. Not at once can there be a realization of what it means to be cut off from such a forceful personality. In her home, in her church, in her town, in her 
State, Mrs. Sprunt was a power. Gifted with many accomplishments, gracious and graceful in manner, a keen, initiative mind, she was fitted to adorn any station in life. She had a vital energy and a tenacity of purpose which overcame obstacles that might have daunted a less indomitable spirit. But greater than these attributes was the wonderful spontaneousness of her generous nature; her every impulse was to help. Only to mention in her hearing a case of need or suffering was to secure immediate assistance, but given so unostentatiously that few knew of her many charities. Among her good deeds stand out prominently her work among the crippled children in the mill village of Delgado and the Marion Sprunt Playgrounds in the various sections of the city. Truly the children may rise up and call her blessed!

Even in these months of illness her everactive mind was devising schemes for the alleviation of suffering, and her whole heart was in the baby hospital which is to be erected as a memorial to her little daughter.

Mrs. Sprunt was for eight years president of the North Carolina Society of the Colonial Dames of America, and at the time of her death its honorary president. Under her wise administration the scope of the work of the society developed and expanded, and through her unusual ability she also made her place in the national society. 
During months of suffering, borne with patience and unselfishness, Mrs. Sprunt's natırally religious nature grew more intense, her mind dwelt upon the eternal verities. A life so full of noble deeds, consecrated to God, is its own memorial.

"When the sun in all his state Illumined the eastern skies, She passed through Glory's morning gate And walked in Paradise."

-Gabrielle de Rosset Waddell.

I count myself very fortunate to have had the privilege of friendship with Mrs. James Sprunt.

She was of the highest type of Southern womanhood-gentle, earnest, courteous, and kind.

Steeped in the history and tradition of her State, she not only exercised an intelligent influence over the Colonial Dames of North Carolina during her long presidency, but she took a broad interest in general history and did much to increase its study and preservation.

As a hostess she was unrivaled, and many of us remember with delight the hours spent at her beautiful home in Wilmington and at Orton plantation.

At the national councils of the Colonial Dames of America, held in Washington. 
D. C., in 1908, I910, and I9I2, Mrs. Sprunt made an enviable reputation. She served on two of the most important committees-the Committee on the "Jamestown Memorial" and the Committee on "Historic Research." Her exhaustive and valuable report on "Unmarked Historic Sites in North Carolina" elicited much praise, as did her report as chairman of the "Necrology" Committee.

A staunch supporter of the church and advocate of all movements for the relief of humanity, a warm friend, a wise counselor, a devoted wife and mother, the loss of her trustful personality will long be felt.

-Kate Cabell Cox.

I count it a privilege to add a personal word to the many and well-deserved tributes which are being paid to the character and the noble and endearing qualities of the honorary president of the North Carolina Society of the Colonial Dames of America, Mrs. James Sprunt, whose loss we are called upon to mourn.

It is true that I only knew her at the several meetings of the biennial council of the national society, which we both attended; but a few such meetings were quite enough for her to make a deep and lasting impression as a woman of unusual attributes, sweet and gracious, gentle and yet strong, giving of her best 
without measure to the cause that appealed to her mind and to her heart.

By one of those singular coincidences which it is hard for us to believe are due to chance alone, the last time that she attended a council she prepared and read the report of the committee appointed to render our last tribute of praise and affection to those of our number who had gone, to be with us no more on earth. I cannot do better than to quote her own words, which come to us now as an evidence of her own steadfast faith: "The confidence of our hope and calm trust that those missed from our side have been given at last the order to advance, to use at length, "in the fullgrown energies of heaven,' the strength, the experience, and the power acquired in the lowlier earth life."

-Clarinda Pendleton Lamar.

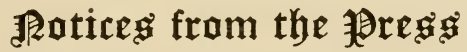

(The Morning Star, Wilmington, N. C., February 17, 1916.)

The news of the death of Mrs. James Sprunt, which occurred this morning, at $2: 15$ o'clock, at her home, No. 400 South Front street, will be learned with profound sorrow by hundreds of people in Wilmington and elsewhere. She had been ill for more than a year, and for the past ten days her condition 
had been critical. She appeared to be better yesterday, however, and it was hoped that she might recover. However, she grew worse last night and passed peacefully away early this morning.

She was the daughter of the late Col. Kenneth Murchison and was married about 30 years ago to Mr. James Sprunt. Surviving, besides her grief-stricken husband, is one son, Mr. J. Laurence Sprunt; a brother, Mr. Kenneth Murchison, of New York, and three sisters, Mrs. Shirley Carter, of Baltimore; Mrs. Ellis, of Atlanta, Ga., and Mrs. Hurkamp, of Fredericksburg, Va.

The death of Mrs. Sprunt removed from the city one of its most beloved Christian women. She was of a most charitable and kindly disposition and will be sorely missed by the many who were the recipients of her kindness.

The funeral arrangements will be announced later.

(The Morning Star, Wilmington, N. C., February 18, 1916. $)^{\circ}$

Her life abounding in deeds of sweet charity and good works and the one distinguishing trait of her fine Christian character being her utter disregard of self in her beautiful devotion to others, the announcement of the 
death of Mrs. Luola Murchison Sprunt, beloved wife of Doctor James Sprunt, which occurred at her home in this city, at fifteen minutes after two o'clock, yesterday morning, though not wholly unexpected, came as a profound shock to the community, which had for so many years been the beneficiary of the influence of her beautiful living.

Individually and in co-operation with her distinguished husband, now so deeply bereaved, Mrs. Sprunt had contributed in many ways to the alleviation of suffering, to the advancement of the Christian cause, and to the sum total of human happiness in the community in which she lived, one of the latest of such beneficences being the founding of a hospital for children and mothers in connection with the James Walker Memorial Hospital in this city, to be known as the Marion Sprunt Memorial, a great work that she had lived to see only started and in the contemplation of which she had taken a deep and abiding interest. In many other ways she and Dr. Sprunt had also contributed largely, in various charities and philanthropies, to the betterment of mankind, especially children, to whom both were ever tenderly devoted, knowing neither class nor distinction in the bestowal of their charities.

Among hundreds of callers at the Sprunt home yesterday, many little incidents of the beauty and kindliness of her spirit were re- 
counted, numerous little deeds of kindness and charity of which perhaps the world never knew, for in the practice of her good works she was singularly unostentatious. Intimation, rather than appeal, was all that was necessary in bringing a ready and a most handsome response to any call of distress or suffering, and all the recompense expected was the consciousness of duty well performed. There are many who in this hour will rise up and indeed call her blessed, as was so splendidly expressed by a friend on yesterday.

Mrs. Sprunt's beautiful devotion to her family and to the enjoyment of her home and fireside were also marked, and one of the last and most striking manifestations of this ruling passion for the comfort and enjoyment of others was her personal direction of a rearrangement and refurnishing of the handsome library in the Sprunt home, which was the special joy and pride of Mr. Sprunt, and where he spent so many happy hours in the company of his books, his letters, and works of art with which the library is enhanced and adorned, as befitting one of his literary tastes and attainments. While still confined to her room in the early stages of her last illness, ever mindful of the wishes and comfort of her husband, she, at great sacrifice, no doubt, of personal feeling, drew the plans for changes and conveniences and later personally supervised the work of skilled workmen requi- 
sitioned to carry out her special ideas and wishes in rehabilitating this room.

As stated yesterday morning in the brief announcement of Mrs. Sprunt's death, just before The Star went to press, she had been in failing health for more than a year, and though the most eminent specialists had been called into consultation and she had spent some time in Baltimore and elsewhere under their especial care, all that could be done availed nothing in the end, when she passed quietly and peacefully away, surrounded by loved ones and those who had ministered so lovingly to her for the long weeks that she had suffered.

Hundreds of friends called at the home yesterday to pay their respects and to utter a word of sympathy to those so deeply bowed down in grief, while many telegrams and expressions of sympathy came from friends and relatives out of the city, many of whom will be in Wilmington today for the funeral, which will be conducted at the home, on South Front street, this afternoon at 3:30 o'clock, Rev. J. M. Wells, D. D., pastor of the First Presbyterian Church, officiating, assisted by the Rev. Dr. Alexander Sprunt, of Charleston, S. C., a brother of Dr. Sprunt, who arrived yesterday to be with his brother and other members of the family in their sorrow. The interment will be in the family lot in Oakdale Cemetery. 
Mrs. Sprunt was a daughter of the lamented Colonel Kenneth M. Murchison, of Wilmington and New York, so highly esteemed in Wilmington and North Carolina, and she was married to Dr. Sprunt thirty-two years ago, their wedded life having been one of beautiful devotion, each to the other. Surviving her are her husband and one son, $\mathrm{Mr}$. J. Laurence Sprunt; a little grandson, J. Laurence Sprunt, Jr.; a brother, Mr. Kenneth Murchison, a distinguished architect of $\mathrm{New}$ York, and three sisters, Mrs. Frank Ellis, of Atlanta, Ga.; Mrs. Shirley Carter, of Baltimore, and Mrs. C. H. Hurkamp, of Fredericksburg, Va. A number of absent members of the family arrived last evening and others will reach here this morning for the funeral services.

Mrs. Sprunt was best loved and admired by those who knew her most intimately, and the following tribute by a personal friend was handed The Star yesterday as expressive of the feeling of a great many who enjoyed her friendship and the influence of her fine personality:

\section{A Tribute.}

It is often so that not until the evangel of better things, of hope fulfilled, of faith justified, comes to claim as its own the life accomplished, do we realize in its fullness the richness of living. To get the most out of life, to 
use every faculty of heart and mind in the service of doing good, is the highest justification of the Christian faith and the truest exemplification of the Christian ideal.

Such was the life of Mrs. Luola Murchison Sprunt. The poor will rise up and call her blessed.

$-A$ Friend.

(The Morning Star, Wilmington, N. C., February 19, 1916.)

In the presence of a large gathering of sorrowing relatives and friends, the funeral of Mrs. James Sprunt, whose death occurred early Thursday morning, was conducted yesterday afternoon at $3: 30$ o'clock from the residence, No. 400 South Front street. The services were conducted by Rev. Dr. J. M. Wells, pastor of the First Presbyterian Church, assisted by Rev. Dr. Alexander Sprunt, of Charleston, S. C.; Rev. Watson Fairley, of Fayetteville, and Rev. Dr. A. D. McClure, pastor of St. Andrew's Presbyterian Church.

There were many beautiful floral tributes, including a large number from individuals and many from organizations with which Mrs. Sprunt had been identified or in which she had been interested. The remains were borne tenderly to Oakdale Cemetery and the interment was in the family lot.

The choir of the First Presbyterian Church sang several selections. "Peace, Perfect 
Peace" and "For All Who from Their Labors Rest" were sung at the residence and "How Firm a Foundation" at the cemetery.

The pallbearers were as follows: Honorary-Mr. B. F. Hall, Mr. W. H. Sprunt, Eugene S. Martin, Esq., Dr. E. J. Wood, Mr. Gilbert P. Kidder, Mr. Isaac Murchison, Mr. Clayton Giles, Sr., and Mr. H. C. McQueen. Active-Col. Walker Taylor, of Wilmington; Dr. W. S. Baer, of Baltimore, Md.; Mr. Charles Hurkamp, of Fredericksburg, Va.; Mr. Shirley Carter, of Baltimore, Md.; Mr. Frank Ellis, of Atlanta, Ga.; Mr. Kenneth Murchison, of New York; Mr. J. W. Murchison and Mr. John R. Murchison, of this city.

Among the out-of-town friends and relatives here for the funeral were the following:

Mr. and Mrs. Charles Hurkamp, of Fredericksburg, Va.; Mr. Kenneth Murchison, of New York City; Mr. and Mrs. Frank Ellis, of Atlanta, Ga.; Mr. and Mrs. Shirley Carter, of Baltimore, Md.; Mrs. James Kyle, of Goldsboro; Mr. J. Hunter Wood, of New York City; Dr. and Mrs. W. S. Baer, of Baltimore; Mrs. J. A. Holmes, of Washington, D. C.; Rev. Dr. Alexander Sprunt, of Charleston, S. C.; Mr. D. H. Lippitt, of Washington, D. C. ; Mrs. Price, of Baltimore, Md.; Mr. Dalziel Sprunt, of Davidson College; Dr. J. G. de R. Hamilton, of the University of North Carolina; Dr. W. J. Martin, 
president of Davidson College; Mr. Isaac Murchison, Misses Lula Murchison, Kate Horner, Kate Fairley, Mr. Marshall Williams, Mr. R. W. Bidgood, Rev. Watson Fairley, Mr. and Mrs. Pemberton, Mrs. McDiarmid, of Fayetteville; Dr. Thomas Sprunt, of Baltimore, Md.; Mr. Brown McKoy, of Charlotte; Capt. Walker Meares, of Faison.

(The Evening Dispatch, Wilmington, N. C., February 17, 1916.)

Mrs. James Sprunt, who for more than a year had been in failing health and for the past few weeks in a critical condition, died this morning at 2:I 5 o'clock, passing peacefully into that existence to which she had faithfully and confidently looked forward throughout her life.

Her death has caused a wave of sincere sorrow in Wilmington, and much sympathy has been expressed for the husband, who so tenderly loved her, and for the others who were near to her.

The funeral arrangements have not been definitely made. It is likely, however, that the service will be held Friday afternoon, with interment in Oakdale. Rev. Dr. J. M. Wells, pastor of the First Presbyterian Church, will conduct the service. 
Mrs. Sprunt was known for her kindliness and grace, and for her devotion to the cause of her Master. Standing like monuments along the pathway of her life are countless acts of charity, and many there are among the poor who in her death have lost a true and valued friend.

Mrs. Sprunt was the daughter of the late Col. Kenneth Murchison, of this city, and was married 32 years ago to Mr. James Sprunt. Surviving her are her husband; a son, $\mathrm{Mr}$. Laurence Sprunt; a grandson, Laurence Sprunt, Jr.; a brother, Mr. Kenneth Murchison, of New York, and three sisters, Mrs. Ellis, of Atlanta, Ga.; Mrs. Shirley Carter, of Baltimore, and Mrs. Hurkamp, of Fredericksburg, Va.

A number of relatives and friends from out of the city are expected to be here tomorrow to attend the funeral. Many telegrams of sympathy have been received today by Mr. James Sprunt and other members of the family.

(Evening Dispatch, Wilmington, N. C.)

$$
\text { M'rs. James Sprunt. }
$$

(An Appreciation.)

When it was known this morning that Mrs. Sprunt was dead, the question was heard on every lip, "Was there ever in this whole city any one who did more for the civic good or 
whose life was more devoted to ministering to the sorrows and infirmities of others?"

Every one who had ever had the slightest dealing with her remembered now that he had felt during the contact, no matter how brief, the strength of her character and a sense of courage imparted to him.

To the poor she came with material conforts; to the sick she came with plans looking to their restoration to health and strength; to her friends she came in every crisis, in every difficulty of their lives and with unfaltering purpose and untiring devotion shared and lightened their burdens; to her family, to her husband, to her children, she has been the very center of life. Her love seemed almost inspired and indeed it had its well-spring in the eternal God Himself, to Whose care she was continually confiding her dear ones, and to Whom so many were given for the everlasting keeping.

Mrs. Sprunt had been a semi-invalid for more than a year, and to those who were near her it seemed as though she realized the time was short and spent every minute doing something for some one in need of material or spiritual things or else in planning now a hospital, now a school, now a church-always something for the amelioration of suffering or the uplift of humanity.

One felt, however, that Mrs. Sprunt withdrew herself from all publicity. She was re- 
served in disposition and countless instances of kindness were of a secret nature and held sacred by her. She so often expressed her human weakness, while at the same time rejoicing in her privilege of service; indeed this feeling of hers seems aptly expressed in a stanza of Tennyson's "Human Cry":

"We feel we are nothing-for

All is Thou and in Thee;

We feel we are something-that

Also has come from Thee;

We know we are nothing-but

Thou will help us to be.

Hallowed be Thy name-

Hallelujah!"

\section{Iteğalutiong}

"They shall abundantly utter the memory of thy great goodness."

Winter Park, February 29, igi6.

Dr. James Sprunt, Wilmington, N. C.

Dear Doctor Sprunt: The elders and deacons of the Winter Park Presbyterian Church met this evening for the consideration of several matters relating to the work of our church, and naturally we gave much thought to the new building which you have provided for us. We feel that the good impulses which prompted you to make this splendid gift to us should find a ready response on the 
part of our congregation, and we anticipate a good and useful career for our church. We value your interest in us and your example of devoted Christian service. While we shall bear in mind the memory of Mrs. Hall, to whose sweet Christian character the church stands as a monument, we shall also always hold you, the donor, in grateful remembrance. May the Lord bless you with all spiritual blessings in Christ Jesus our Lord!

We were speaking tonight of your great bereavement. The Lord has made you to pass through deep waters, but we know His sustaining hand will not fail you and that His peace will not depart from you. We realize how pleasant it would have been for you to have had Mrs. Sprunt to be present with you at the dedication services. But we believe she will share the pleasure with you from her vantage ground of light.

Our best wishes and most affectionate interest will always be with you, dear Doctor Sprunt.

Sincerely your friends,

R. T. Sinclair,

G. W. SHePhard,

C. M. Robinson,

L. D. Latta,

Deacons.

G. C. McIntire,

EARL W. JONES,

Elders.

Andrew J. Howell, Pastor. 
First Presbyterian Church, Wilmington, N. C.

March 6, I 9 I 6.

\section{James Sprunt, LL. D.,}

\section{Wilmington, N. C.}

DEAR BRother: The members of the session have had you on their hearts and the dedication of the Winter Park Memorial Church-a daughter of this church-affords another occasion to tell you of our appreciation of your and your sainted wife's service, not only in the personal work of consecrated lives, but in the princely gifts to the cause of our Lord. They are enshrined in the hearts of our people here and in far-away China. Many of them doubtless will never be known until revealed at the last day, when the Book of Life is opened.

The session orders that this feeble expression of our approbation be written in the church's book of minutes and a signed copy be transmitted to you.

Faithfully your friends,

J. A. SPRinger.

Will Cumming.

A. M. Hall.

J. G. MURPhy.

C. W. WORTH.

WALKer TAYLOR.
John M. Wells.

C. H. Robinson.

B. F. Hall.

P. Pearsall.

R. A. BRAND.

H. C. McQueEn. 
Mr. James Sprunt, Wilmington.

DEAR FRIEND: The officers and congregation of the Chesnut Street Presbyterian Church extend to you, in your bereavement, tenderest sympathy.

"My grace is sufficient for thee."

DAVID BRYANT,

JoHN MCRAE,

LOUIS BELDEN,

W. H. BRADlEY,

J. E. TAYLOR,

G. D. Hargrave,

Deacons.

James D. DRY,

AARON KELLOGG,

J. A. Hargrave,

C. A. KING,

J. A. Murray,

Elders.

Wilmington, N. C., Feb. 23, i 9 i 6.

Whereas, Mrs. James Sprunt has attained unto the full measure of her earthly labors, through her mission of service, her works of love and charity, and has through the providence of God been removed from the midst of the citizens of Wilmington and called into her eternal reward:

$\mathrm{Be}$ it therefore resolved, That we pause to pay an humble tribute to her Christian devo- 
tion and her whole-soul endeavor to help men and women, irrespective of creed and condition.

Be it further resolved, That we express to the bereaved husband and other members of the family our deep and sincere sympathy, and that a copy of this resolution be spread upon our Daily Journal and that a copy be also sent to the bereaved family.

Done on the behalf of the colored ministerium of the city of Wilmington, N. C.

$$
\begin{aligned}
& \text { J. FRANCIS LEE, } \\
& \text { Secretary. }
\end{aligned}
$$

"The King's daughter is all glorious within."

Mrs. James Sprunt.

Entered into Rest February I7, 19 I6.

It is with a deep sense of loss and profound sorrow that the ministering circle of the King's Daughters records the death of Luola Murchison Sprunt.

In her death we mourn a valued and a faithful member, for in all her walks of life she was a true King's Daughter. Her life abounded in thoughtful kindness and no charity appealed to her in vain.

In large-heartedness, hospitality, and loyalty to all things worthy, her life will stand as an example of truest womanhood. What her 
hand found to do, she did it with all her might, and in speaking of her we can lovingly utter the grand words of Solomon: "Give her of the fruit of her hands; let her own works praise her in the gates."

In the closer personal relations of life as wife, mother, sister, and kinswoman, her life left nothing to be desired; as a friend, she was an able counselor, and those who knew and loved her best feel that her life was a benediction.

$$
\begin{aligned}
& \text { "Weep not that her toil is over, } \\
& \text { Weep not that her race is run; } \\
& \text { God grant that we rest as calmly } \\
& \text { When our work, like hers, is done." }
\end{aligned}
$$

Therefore, be it resolved, That a page in the minute book be inscribed to her memory and a copy of this resolution be sent to the bereaved family.

$$
\begin{aligned}
& \text { Sue McQueen. } \\
& \text { Fanny M. Curtis. } \\
& \text { E. Williams. } \\
& \text { Wilmington, N. C. }
\end{aligned}
$$

Young Women's Christian Association. Wilmington, N. C., March I, igr6.

Whereas our God has taken to Himself the spirit of Luola Murchison Sprunt, the beloved wife of Dr. James Sprunt; and 
Whereas Mrs. Sprunt was a promoter and liberal supporter of every movement for good; and

Whereas Mrs. Sprunt was a member of the South Atlantic Field Committee of the Young Women's Christian Association and a life member of this association, in which she was deeply interested: Therefore be it resolved by this board of directors:

First. That we tender to her husband and son our sympathy and our offer to do anything in our power to make her memory precious, as it deserves to be.

Second. That we record in our minutes the statement that the life of Mrs. Sprunt and her labors were fruitful in kindness and beneficence to all whom she could reach; and,

Third. That we cherish her memory and desire to have a part in her spirit and disposition to help others.

Fourth. That a copy of these resolutions be sent to her family, and that the secretary be instructed to inscribe these resolutions in the minute book of our association.

Mrs. A. D. MCCluen.

Miss Anne P. Kidder.

Mrs. H. Louis Vollers. 
"For tho' from out our bourne of time and place The flood may bear me far,

I hope to see my Pilot face to face

When I have crossed the bar."

Board of Commissioners of Navigation and Pilotage for Cape Fear River and Bars.

\section{Wilmington, N. C.}

Having learned with deep regret and profound sympathy of the death of Mrs. Luola Murchison Sprunt, wife of our Honorable Dr. James Sprunt, a special meeting of the Board of Commissioners of Navigation and Pilotage was held on this seventeenth day of February, nineteen hundred and sixteen, and the following action taken:

Whereas God in His infinite wisdom has seen fit to take to Himself Mrs. Luola Murchison Sprunt: Be it resolved:

First. That the Board of Commissioners of Navigation and Pilotage feels that the entire community has suffered a personal loss. Hundreds of homes, from the lowliest to the highest, will remember her in some work of kindness, some word of comfort and encouragement. Her sympathy for every one in distress was manifested wherever there was the slightest opportunity for her to express it, and she never neglected an occasion to say a word of consolation and Christian cheer.

Second. That the Board of Commissioners 
of Navigation and Pilotage shares in a large degree the bereavement, not only because of its deep appreciation for the beautiful character of Mrs. Sprunt, but for the great esteem of its chairman, Dr. James Sprunt, whose personality has always deeply impressed the board.

Third. That these resolutions be engrossed upon our records and a copy be sent to Dr. Sprunt.

$$
\begin{aligned}
& \text { John W. Harper, } \\
& \text { Vice-Chairman. } \\
& \text { H. G. SMALlbones, } \\
& \text { WM. St. GEORGE. } \\
& \text { T. F. WoOD. } \\
& \text { E. D. Williams, } \\
& \text { Harbor Master. } \\
& \text { Jno. T. Rankin, Clerk. }
\end{aligned}
$$

"Virtutes majorum filiæ conservant."

The North Carolina Society of the Colonial Dames of America records with deep sorrow the death of Luola Murchison Sprunt.

Whereas the North Carolina Society of the Colonial Dames of America recognizes that in the death of Mrs. James Sprunt it has lost a member whose strong personality and keen judgment marked her as a power in the society, and whose eight years of administra- 
tion as president were conspicuous for achievements, of which the society is justly proud:

Therefore be it resolved:

I. That Mrs. Sprunt's administration was constructive, embracing a large scope of work, the trend of which was unified by her great aim-to do honor to the virtues of colonial forefathers, and to encourage in all who come under the influence of the society a true patriotism, built on a knowledge of the selfsacrifice and heroism of those men of the colonies who laid the foundation of this great nation.

Notable among her services to the society were the establishing at the University of North Carolina of two yearly prizes for essays on colonial subjects, thus stimulating the interest of the young manhood of the State in the virtues and exploits of the founders of their Commonwealth; the marking of historic spots throughout the State with granite boulders; the much-needed revision of the society register, and her faithful guardianship of St. Philip's Church and graveyard.

Her ability was not confined to the activities of her State society, for she served with distinction on important committees of the national society.

2. That as presiding officer the resourcefulness with which Mrs. Sprunt met and disposed of many vexed questions, her graceful 
dignity and gentle courtesy will ever be remembered.

Seldom has it ever been the pleasure and privilege of any society to enjoy such beautiful hospitality as was annually extended to the North Carolina Society of the Colonial Dames of America by this, its beloved president.

Along all lines she lived her life intensely, not for herself, but for others, for-

"Knowledge through suffering entereth, And life is perfected through death."

3. That a copy of these resolutions be spread upon the minutes of the society, a copy sent to the national society of the Colonial Dames of America, and a copy sent to her family.

Mary Fairfax Gouverneur,

Frances Latham HaRriss,

Florence Hill Kidder, JR.,

Committee.

The Wake County Committee of the North Carolina Society of Colonial Dames of America having heard of the death of Mrs. James Sprunt, of Wilmington, N. C., by a rising vote pass the following resolutions:

The North Carolina Society of Colonial Dames have lost a true and loyal member, whose life has been an inspiration to all who 
knew her. Her untiring efforts when president, in which she was unsparing of herself and her time, and from her own resources placed memorials to the honor and memory of those deeds of our colonial forebears which reflected credit on our State.

Her rare personal charm and graciousness of manner endeared her to all. Her hospitality, not only to our own members, but to legions of friends, was noted throughout our State and elsewhere. Her home life was perfect. She was a devoted and earnest christian, a woman whom it was a privilege to have known, one whose place can never be filled, for there was but one Luola Murchison Sprunt. This society extends its deepest sympathy to the bereaved husband, son, and grandson.

Therefore it is ordered that these resolutions be entered on our minutes and a copy sent to Mr. James Sprunt and to the North Carolina Society of Colonial Dames at Wilmington, N. C.

Augusta Webb Ford Andrews.

Jane Evans Elliot McNeill.

Emily Benbury Haywood. 
North Carolina Society of the ColonialıDames of America in Wayne County.

Inasmuch as God has seen fit to take away one of our most beloved members, Luola Murchison Sprunt, the Wayne County Committee extends their heartfelt sympathy.

As one of our members who was always willing and ready to answer to every call, she will be greatly missed.

\section{BARBARA ISLER KYLE,}

Secretary.

The Forsyth County Committee of the North Carolina Society of Colonial Dames of America desires to express to Mr. James Sprunt and family heartfelt sympathy in their recent great bereavement.

Wilmington, N. C., Feb. 24, i9i6.

The North Carolina Society of Colonial Dames of America express their sorrow for the loss of one who has been their efficient leader for many years. Of her time and strength she gave freely to others, and was ever a "cheerful giver," such as God loves. "Very sincerely yours,

Jane Iredell Williams,

Chairman. 


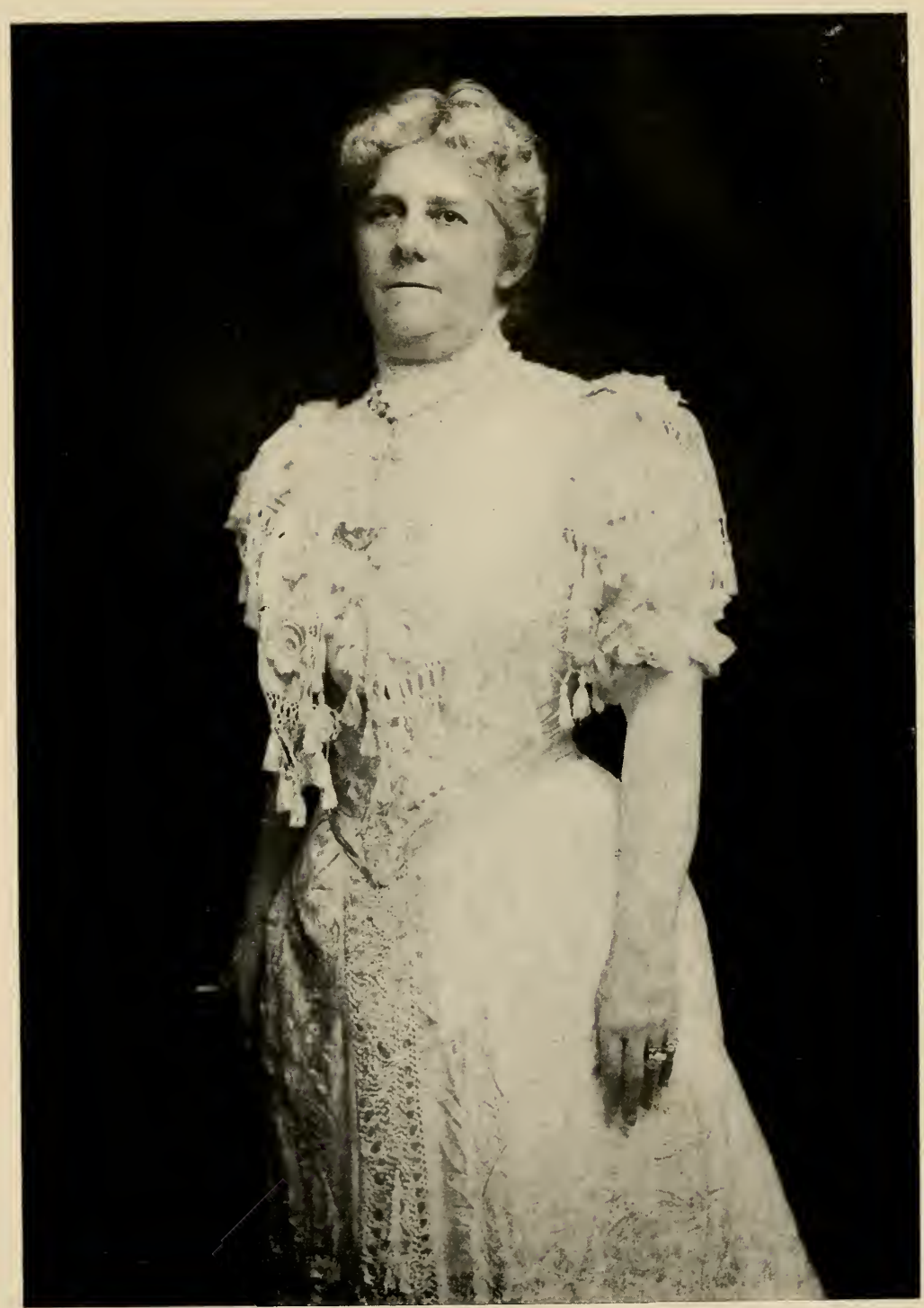

LUOLA MURCHISON SPRUNT

President of the North Carolina Society of

Colonial Dames of America, 1906-1912 
(Excerpt from the "Report of the Committee on Memorials," Made to the Annual Meeting of the Society of Colonial Dames, Held in May, 1916.)

"A little while" and again we were called to suffer another great loss, for Mrs. James Sprunt finished her earthly pilgrimage and entered rest eternal! For eight years she was president of the North Carolina Society of Colonial Dames of America, and later honorary president. Our hearts were wrung with sorrow, for had we not all admired her splendid achievements in the society, her constant thought and work for its best interests, and her ambition to have the North Carolina Society of Colonial Dames take the place in the world that she felt was its due? Had we not all enjoyed her wonderful hospitality, being made to feel that'we were granting her a favor rather than having it bestowed upon us? Ever courteous and gracious, going smoothly along in her splendid works, hurting no one by words hastily spoken or unkind deed. We planned, perhaps, better than we knew when we requested her to fill the office of president, as all of her good work proved through the years of active service. One part of the work of the society was ever very close to her heart, and the love and care she has bestowed on old St. Philip's has made others realize what a grand old historical spot is the ground occupied by the church and its graveyard. With a heart full of sympathy, no 
doubt she has stood many a time by those ancient graves and thought of the beautiful services held in those old church walls, in which the same people "at rest" now for more than a century, participated, praying from the depths of their hearts and singing the old-time hymns, as "How Firm a Foundation, ye saints of the Lord, is laid for your faith in His excellent Word," until the very woods around echoed with those prayers and melodies, which were being wafted on gentle breezes to the great white throne. Her own "faith in His excellent Word" carried her through much suffering and great weariness and she never yielded to bodily suffering to the exclusion of constant thought of others. Nor did her interest in this society ever wane. Perhaps one of the last times she ever used a pen was to sign, with satisfaction to herself, an application blank for a new member.

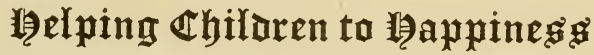

"And with the morn those angel faces smile,

Which I have loved long since and lost awhile."

The Marion Sprunt Playgrounds.

Bearing the name of their dearly loved and beautiful daughter, these plavgrounds, four or five in number, established by $\mathrm{Mr}$. and Mrs. Sprunt in various parts of Wilmington, have 
brought pleasure and happiness to numberless little ones. They gave Mrs. Sprunt much satisfaction, and she was always active in promoting and extending their good influence. In this work she felt in touch with the lovely child whom God had taken unto Himself, but who was ever present in the mother's heart.

"A mother is a mother still, The holiest thing alive."

It is safe to say that no work in which Mr. and Mrs. Sprunt have co-operated has been more valuable for lasting good.

"And whoso shall receive one such little child in My name receiveth Me."

\section{The Delgado Kindergarten School.}

At the Delgado Cotton Mills, which are located near Wilmington, N. C., Mr. and Mrs. Sprunt established the Delgado Kindergarten School. They erected a building suitable for the needs of some fifty children below the age of public schools. The children are furnished with a substantial meal every day while their parents are at work in the factories. This undertaking is carefully looked after by two excellent teachers in combination with other competent persons. It has greatly benefited the Delgado settlement and has elevated the character of the people. A play- 
ground for the children adds greatly to this beautiful mission, and Mrs. Sprunt received much satisfaction in directing this pleasure for the little ones. The following letter, received by Mr. Sprunt from the president of the Delgado Mills, is a gratifying expression as to the work accomplished by the school and playground:

"I wish to express my sympathy in your great loss of your noble, good wife; also that of all our people here at Delgado. They feel that they have lost a friend who had a feeling of sympathy for them in all their efforts, and I want to express this to you for them. I know that you can see the good that you both have done for all of these people, and especially the little ones, whose lives are being made happier and guided aright. The opportunity of early training in right living and righteousness is an immeasurable gift. For the many kindnesses and interest you and Mrs. Sprunt have given them they and I have grateful hearts.

Yours most sincerely,

E. C. Holt."

\section{Immanuel Presbyterian Church.}

Mr. and Mrs. Sprunt were greatly interested in the progress of Immanuel Presbyterian Church, in the southern part of Wilmington. They contributed a number of 
gifts in property and buildings. The school connected with this church has become one of the largest in the city, and Mr. and Mrs. Sprunt gave their hearty sympathy to its growth and development. Mrs. Sprunt's special work here was the playground for the children. It is called the Marion Sprunt Playground, and was the first in the city of Wilmington.

\section{Atighiong}

"Proclaim to every people, tongue, and nation

That God, in Whom they live and move, is love:

Give of thy sons to bear the message glorious;

Give of thy wealth to speed them on their way;

Pour out thy soul for them in prayer victorious;

And all thou spendest Jesus will repay."

\section{The Kiangyin Station.}

From far-off China comes the solace of believing prayer and the assurance that those whom she had led into paths ending in heaven honored and held onto her still. At this mission Mr. and Mrs. Sprunt had founded and sustained schools for instruction in practical studies and contributed to a hospital for the suffering, at an outlay of many thousands of dollars. The staff, consisting of a dozen teachers from her own Southern people, a score of native teachers and a multitude of children joined in the memorial services, held the Sunday following her death. 
Southern Presbyterian Mission,

Kiangyin, China.

Feb. 16, I9 6.

I wish you knew what a wave of sympathy and prayer was stirred in all of our hearts by your cable message four days ago. From the hour we received it there has been constant remembrance of Mrs. Sprunt and yourself. At noon every day the whole station meets for prayer, and at that time you are lovingly held up to God and in our private prayers regularly. The cablegram reached us on Saturday and all of us were touched deeply that you should have thought to reach out to us, half around the globe, to bring us, too, within the circle of prayer that we know is going up from the host that love you both. On Sunday morning at church Mr. Moffett told the congregation of your message asking for prayer; that it had brought the ends of the earth close together, of your faith in prayer, and that you wanted the prayers of your Chinese fellow-believers. He then called upon a deacon and an elder to lead in a petition for Mrs. Sprunt and yourself. The elder is a college graduate and principal of the James Sprunt Academy. He thanked God that, though we were so far distant and could not show our hearts to you nor do anything for you, yet we were close together in prayer. $\mathrm{He}$ asked for God's blessing upon Mrs. 
Sprunt's physicians, nurses, and all who are with her, and finally that deep peace might be given to you both-as he put it, "the fullness of the peace of God" might fill your hearts. And now I may say that this is the keynote of all our prayers. We do not know whether it has pleased God to spare Mrs. Sprunt for further loving service, but we pray that it may be so, and we trust that through the many prayers going up for you that this may be a time of rich blessing for you both. We are remembering you specially at this time and with deep sympathy, but you are not forgotten at any time. Your cablegram has been a blessing to us all, and I wish you could see how much comfort it has given us that we could flash back our sympathy.

Yours affectionately,

George C. Worth.

Southern Presbyterian Mission,

Kiangyin, China.

Feb. I 8, I9 6 .

We are planning a memorial service for Sunday morning. Of this you will hear more in detail later. We feel that it will be a real blessing to our Chinese, not only because it will bring before them afresh the beautiful life of your dear one, but also because it will be a good opportunity to show them how we still 
honor, love, and possess our departed. They feel because our doctrine forbids worship of the dead that they are forgotten and unhonored.

Our special prayer for you is that you may be so conscious of spiritual fellowship with your beloved wife that you may feel in a true sense you still have her. We rejoice that hers is already the rest that remaineth for you and us. Your friend sincerely,

Ella Ward Allison.

\section{Presbyterian Church in U. S.}

North Kiangsu Mission, Tsing Kiang Pu.

To Mr. James Sprunt:

Feb. I 8, I 9 I 6.

In thinking of her I think of the many who would say of her: "Blessed are the dead who die in the Lord, that they may rest from therr labors, and their works do follow them."

Yours most affectionately,

Nell Sprunt.

Southern Presbyterian Mission,

Kiangyin, China.

February 19, i9i6.

How wonderful it must be for dear Mrs. Sprunt to be freed from all suffering and 
weakness and to rejoice with all her marvelous capacity for joy in the eternal bliss of the Father's home! Surely our dear departed ones are not far away and certainly we have not lost them; they are perhaps more truly ours than ever before. Could dear Mrs. Sprunt speak to you now, what a wonderful, wonderful story she would have to tell and what words of comfort she would speak! Her memory is most fragrant in Kiangyin, and you and she mean so much to the peopie here that we felt we must have a memorial service; it will be held in the church tomorrow (Sunday) morning, and we are praying that it may be a time of great spiritual upbuilding for the Kiangyin Christians.

Most sincerely,

Ella D. Little.

\section{Kiangyin, China, \\ February 22, I916.}

"Whether we live or die, we are the Lord's."

"When He shall appear we shall be like Him, for we shall see Him as He is."

With deepest sympathy,

Very sincerely yours,

Rida Jourolmon. 
Southern Presbyterian Mission,

Kiangyin, China.

Feb. 20, I 9 I 6.

You have been much on our hearts and in our prayers since word first came of Mrs. Sprunt's illness. We could only ask that His will be done, and though we feel deeply with you in this the great sorrow of your life, we know that you, too, accept His will as from Him in love. There has been constant prayer on the part of the Chinese friends for you both for some days past. They have never seen you face to face, but the bond of sympathy and gratitude is none the less real, and your names are often on their lips.

An old Christian mother said to me some while ago, when I was comforting her over the loss of a son who was her main dependence, "He never plucks the fruit before it is ripe." She was a poor, ignorant old soul in most things, but what a wealth of comfort the Master had given her in that thought that her loved one was ripe for the joy of His presence! Some of us have yet to be ripened more while we serve here, but with what joy our loved ones who have gone before will await and welcome our coming!

We well know that you have taken comfort of Him who shares our every sorrow, but we want you to know that we sorrow with you and bear you daily to the throne of grace, that the light of His presence with you may lighten 
each day's burden and bring the joy of a fellowship which, in His own time, may ripen into the "abundant entrance."

With sincerest love and sympathy from Your co-workers in His service, Mr. and Mrs. Lacy S. Moffett.

A Special Service in Loving Memory of Mrs. Luola Murchison Sprunt, at Kiangyin, China, Feb. 20, 1916.

Invocation Lacy L. Little Hymn-Asleep in Jesus, Blessed Sleep. . The Congregation Scripture-Ist Thess. 4:13-18, Rev. 22:1-5

Elder Tsang Ts-yong

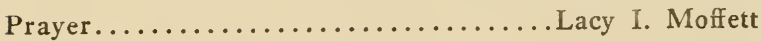
Address-Her Life.................... Geo. C. Worth Hymn-Give Me the Wings of Faith

Choir from the Girls' School Address-What She Has Done for Our Schools

Andrew Allison

Address-Lessons to be Learned from Her Life

Elder Tse Yong-K'ang

Hymn-Take Comfort, Christian..... The Congregation Prayer.......................tder Loh Ping-yong Benediction........................ Lacy I. Moffett

\section{Tsing Kiang Pu, China,}

Feb. 2I, I9I6.

I can't help living over my days at home and recalling the memories of your and Aunt Luola's loving, unfailing, thoughtful ministry to mother and us all.

As always, your loving niece, Jessie Hall. 
Southern Presbyterian Mission,

Kiangyin, China.

February 22, I9I6.

She has suffered much. How sweet the rest of heaven! I am sure our merciful God is helping you to be glad because of her perfect bliss, and He will help you, too, to look forward to the glad reunion in His good time. We are praying that heavenly comfort and peace may be yours as the lonely days go by.

A very helpful memorial service was held in our East Gate Church Sunday morning. Beautiful tributes were paid to the memory of our dear friend, who is not dead, but "alive for evermore." I enclose you a copy of the order of services.

"The Lord be with thee."

$$
\begin{aligned}
& \text { Affectionately your friend, } \\
& \text { LACY L. LitTLE. }
\end{aligned}
$$

\section{Kiangyin Hospital,}

Southern Presbyterian Mission.

February 22, I 9 I 6.

On Sunday the morning service at church was a memorial of Mrs. Sprunt. It was a solemn service and very impressive, for all the congregation felt that a great friend had been called away and another devoted friend was left deeply bereaved. I do wish you could have heard all the words of respect and honor 
and affection that were spoken. I will leave that for Mr. Allison, but I just want to tell you how tenderly we are all bearing you and Laurence up before the One who alone can give you rest of soul and fill the vacant place in your hearts.

Your affectionate,

Geo. C. Worth.

\section{Southern Presbyterian Mission,}

Kiangyin, China.

Translation of Letter from the Kiangyin

\section{Church.}

To the Honorable James Sprunt, most respectful greetings:

We have long heard of the wideness of your sympathy-not making distinction between one country and another-and of your desire to be a servant of all. Looking to God for grace, your heart goes out in great tenderness towards countless multitudes who depend upon you. If the Spirit of Jesus had not been in your heart, how could you have built up our James Sprunt Academy and Luola Murchison Sprunt Academy? It is easy to be seen that we lean upon the strength of your arm. Having obtained these great benefits from you, how can we forget you for one day?

Having heard that our merciful God had called Mrs. Sprunt to the heavenly home, our 
pastor, Mr. Little, at once called a meeting of the congregation in the church to hold a memorial service. We-the whole body of church members-wish, in this feeble way, to express to you our hearts' sympathy and to call your attention to certain passages from God's Word, which we hope will be a means of consolation to you. Please see: Ist Thess. 4: I3-1 4: "But we would not have you ignorant, brethren, concerning them that fall asleep; that ye sorrow not, even as the rest, which have no hope. For if we believe that Jesus died and rose again, even them also that are fallen asleep in Jesus will God bring with Him." Revelation I4: I 3: "And I heard a voice from heaven saying unto me, Write, Blessed are the dead which die in the Lord from henceforth: Yea, saith the Spirit, that they may rest from their labors; and their works do follow them." Isaiah 49: I3 : "Sing, O heavens; and be joyful, O earth; and break forth into singing, $\mathrm{O}$ mountains : for the Lord hath comforted His people, and will have compassion upon His afflicted." Ist Peter 4: I3: "But insomuch as ye are partakers of Christ's sufferings, rejoice; that at the revelation of His glory also ye may rejoice with exceeding joy.'

We respectfully present these few lines, trusting that the peace of Christ may be yours.

The Congregation of the East Gate Church, Kiangyin, China. 
Kiangyin, China, Feb. 22, i 9 i 6.

Your dear wife will be missed by a very wide circle of friends and relatives, and no one can take her place. I am so glad that our school girls here learned to know and love her through her picture and gifts and messages. We are hoping that the letters from the girls reached her before she was too ill to enjoy them; but if not she knows all about it now, and I trust the letters have been a comfort to you. With assurances of love and prayers, Yours affectionately,

Emma C. Worth.

PEACE, PERFECT PEACE.

Peace, perfect peace, in this dark world of sin? The blood of Jesus whispers peace within.

Peace, perfect peace, by thronging duties pressed? To do the will of Jesus, this is rest.

Peace, perfect peace, with sorrows surging round?

On Jesus' bosom naught but calm is found.

Peace, perfect peace, with loved ones far away? In Jesus' keeping we are safe and they.

Peace, perfect peace, our future all unknown? Jesus we know, and $\mathrm{He}$ is on the throne.

Peace, perfect peace, death shadowing us and ours? Jesus has vanquished death and all its powers.

It is enough: earth's struggles soon shall cease, And Jesus call us to heaven's perfect peace. 


\section{Extractg from

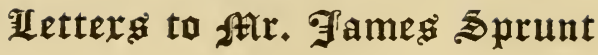

From the many appreciative letters of sympathy only those expressions which speak directly of Mrs. Sprunt have been selected.

The White House,

Washington, D. C., Feb. i8, i 9 i 6.

It was with the deepest sorrow and most genuine and heartfelt sympathy that I learned of the death of Mrs. Sprunt. My heart goes out to you in this bereavement. I hope that you may be sustained by the only sources that avail in such circumstances.

With warmest regard,

Cordially and sincerely yours,

WOODROW WILSON.

Baltimore, Md., Feb. 23, i9i 6.

I desire to offer my sincere condolence in the sad loss you have just sustained by the death of your beloved wife, the account of whose funeral I have read in the Wilmington Star.

Very faithfully yours,

J. Card. Gibbons.

90 


\section{BAltimore, MD., Feb. I8, I9i6.}

I had learned, as had all who had come to know your wife, the unusual beauty and loveliness of her character. The memories of a life so beautiful as hers will be supporting and inspiring. It has been good to know her, and it will be something to watch the development of a beautiful inheritance in the little life which is to perpetuate it to future generations.

Your sincere friend,

\section{W. S. Thayer.}

Legation of the U. S. of America.

San Josk̀, Costa Rica, March I 2, I 9 I 6.

I knew her as a happy child, and later as a young woman of strong character and many graces and accomplishments.

Faithfully your friend,

E. J. Hale.

Chapel Hill, N. C., Feb. i 9, i 9 i 6.

Having gone through the bitter waters, I can most feelingly sympathize with you in your recent bereavement.

Cordially yours,

Kemp P. Battle. 
Supreme Court.

Raleigh, N. C., Feb. 2 I, I9I 6.

I have just learned of your great bereavement. I know quite well how devoted you were to each other; how bitter the sorrow and poignant the grief must be when the tie that has so long bound you together in loving companionship was severed.

With my cordial and best wishes,

Yours sincerely,

Platt D. Walker.

Chapel Hill, N. C., Feb. 25, i 9 I 6.

The greatest of your wife's gifts to others was the loving gift of self, and this she gave unstintingly and unsparingly, even to the injury of health and strength. We could see this when we visited your home, and we loved her for it. There is nothing greater or more lovely.

Your friend,

Francis P. Venable.

Chapel Hill, N. C., Feb. i 8, i 9 i 6.

No words can tell you of my grief and sympathy. May this note assure you of the constancy of my thoughts and prayers for you.

Affectionately,

J. G. de Roulhac Hamilton. 
Chapel Hill, N. C., Feb. i9, igi 6.

May I express to you my very genuine and profound feeling for you at this moment, when one of the greatest blows that fate holds in reserve has fallen.

Your sincere friend,

\section{Archibald Henderson.}

Chapel Hill, N. C., Feb. 20, i9i 6.

It was a great shock to hear of Mrs. Sprunt's death. She was very kind to me, and my memories of her will always be cherished.

Sincerely,

Robert C. Davis.

University of Virginia.

February 29, I 9 I 6.

I send you my love and deep sympathy in your great sorrow. You have been in my mind and heart constantly and tenderly these days past. We poor mortals can only stand by in such moments, suffer with our friends, and support their courage, if happily we can. All this I do, my friend, with a full heart. May the good God comfort and sustain you.

Faithfully yours,

Edwin M. Alderman. 


\section{University of Virginia.}

February 2I, I9I 6.

Having known Mrs. Sprunt, I know also your sense of loss. But may the years bring such an increased realization of your heritage of memory and association that the darkness may be touched with growing light and the temporary loss transmitted into permanent gain.

Sincerely yours,

C. Alphonso Smith.

Wooster, Ohio, Feb. I 7, i 9 i 6.

She is with God and God is with you.

These are the unshakable convictions that will bring you the deepest peace.

Very affectionately yours,

J. Campbell White.

College of William and Mary.

Williamsburg, Va., Feb. i 9, i 9 i 6.

There are many outside of your intimate circle of friends whose hearts have been touched and whose prayers have been moved for you in these dark hours.

Sincerely yours,

James S. Wilson. 


\section{College of William and Mary.}

Williamsburg, VA., March 4, i 9 i 6.

I cannot refrain from expressing to you my heartfelt sympathy. We are not as those without hope, for we feel that this is only another link in the chain that binds us to that world where there is no suffering, and that her departure is but a translation to the realm of everlasting glory.

I remain,

Sincerely,

John C. Calhoun.

\section{Hampden-Sidney College.}

Hampden-Sidney, VA., Feb. - i 9 I 6.

I know well what a void her passing has made in your life, and that the home over which she presided with so much grace and charm, and where she dispensed a hospitality so bountiful and delightful, seems altogether broken and desolate.

The great company of those who experienced her ministries of mercy unite with you in deep grief over her departure, or are waiting to welcome her entrance into the mansions above.

Faithfully yours,

H. Tucker Graham. 
Agnes Scott College, Decatur, Georgia.

I have just read in an Atlanta paper a notice of your wife's death. The prolongation of life to her could only have meant the prolongation of suffering. The change to her has been supremely blessed.

Sincerely yours,

$$
\text { F. H. GaINES. }
$$

Yorktown Historical Society of the United States.

Gloucester, Va., Feb. i 9, i 9 i 6.

I noticed in the "Times-Dispatch" that your dear wife had passed away, and you have my deepest sympathy in your bereavement. You know whom you have believed and His rod is not one of anger but of love, and His grace is sufficient.

Very sincerely,

W. H. Groves.

Wilmington, N. C., Feb. -, i9i6.

Her beautiful life has been such a help and inspiration to so many, and her name shall live always.

Affectionately,

May Beverly French. 
Wilmington, N. C., Feb. I 7, i9i 6.

The profoundest consolation to you at this time will be the sweet memories of long association with an accomplished and noblehearted woman, whose life and character leave behind the beautiful example of a Christian life.

Sincerely,

\section{Iredell MeAREs.}

\section{Wilmington, N. C., Feb. i7, I9i6.}

For many years I have seen her ability to make the world around her so beautiful by the touch of her magic fingers.

Sincerely,

Mary Calder Atkinson.

Wilmington, N. C., Feb. I 7, i9i6.

It always seemed to me that she typified a beautiful combination of gracious dignity and ability.

Most sincerely yours, Mary Fairfax Gouverneur.

Wilmington, N. C., Feb. I7, igi 6.

Mrs. Sprunt was very kind to my father. May her soul rest in peace!

With sympathy, sincerely,

James Owen Reilly. 
Wilmington, N. C., Feb. I7, i9i 6.

With profound sorrow I heard this morning of the passing of your noble wife. But for her it means freedom from suffering and a crown of glory for the good deeds she bestowed upon others during her life.

Your friend,

Rose Barry SMith.

Wilmington, N. C., Feb. i 7, igi6.

I extend to you and your bereaved family my deepest sympathy in the passing away of Mrs. Sprunt. Of this community I am one who has occasion to feel a pang of sorrow. It was just at this season of the year in 1903 , when I had come here from Washington, D. C., to recuperate from a severe sickness, that Mrs. Sprunt driving by the house in her phæton noticed me sitting on the porch of my sister, Mrs. E. D. Sloan. She must have observed my emaciated condition and I had been impressed with her modest bearing and unconscious beauty. A few moments later I was made aware of the identity of this most excellent lady in a beautiful manner by receiving from her a bouquet of the prettiest and sweetest roses I ever saw or expect to see. I was overwhelmed at this manifestation of gentle kindness, but it did me good and I commenced to feel better immediately. 
I cite this as only one of a thousand such kindly acts to others illustrative of the Christian character of this noble lady.

Very truly yours,

Paul D. Satchwell.

Wilmington, N. C., Feb. i 9, i 9 i 6.

Because Mrs. Sprunt's life here was so full of goodness and love, we know that God hath prepared glorious rewards for her in the heavenly home, and that you have lost her "but for awhile."

Sincerely yours,

\section{Leonora Cantwell.}

Wilmington, N. C., Feb. i 9, i 9 i 6.

1 shall cherish always the deeds of kindness which were given so freely by Mrs. Sprunt to my father and the moments of happiness she gave him by her unselfish thought and care. Grace Craig Branch.

Wilmington, N. C., Feb. 2 I, I 9 I 6.

It must comfort you to feel in how many beautiful ways your wife has left her impress upon the community. The influence that she exerted for good will live forever.

Most sincerely,

Eliza W. Meares. 
Wilmington, N. C., Feb. 2 I, I9 6 6.

As president of our "Colonial Society," which she so well represented, she bore herself with that gracious dignity and sweet authority that characterizes the gentle born woman, and which will always keep her memory dear to the hearts of its members.

Sincerely your friend,

Annie M. Baltzer.

Wilmington, N. C., Feb. 22, igi 6.

Irreparable loss has come to you and your family, which is felt keenly and widely through and beyond this whole community.

Sincerely your friend,

\section{Cary Davis MacRae.}

\section{Wilmington, N. C., March 25, I9i 6.}

I have waited a little before writing, as I know so well how overwhelmed you have been with expressions of sympathy for your unutterable loss and with tributes to the beautiful soul whose dear companionship has blessed your life.

Who, among your friends, can feel for you more deeply than I? You knew and loved Bishop Strange and I knew and loved Mrs. 
Sprunt. She was to me "a perfect woman nobly planned," using her splendid gifts to make better and happier every life that she touched. Believe me in great sorrow and sympathy,

Your friend,

Elizabeth S. Strange.

Fayetteville, N. C., Feb. 26, igi6.

Her life was so full of good and her example so beautiful for all.

Sincerely yours,

Roxy Williams.

Fayetteville, N. C., Feb. 29, i 9 I 6.

Lula's death has left a void that no one can fill. Her many deeds of kindness will be told to generations yet to come.

Most affectionately yours,

Kate Williams Bidgood.

Fayetteville, N. C., Feb. 29, r9r6.

I remember Luola with great affection and admiration. It was with sincere grief that I heard of her death.

Your cousin,

Mary MCNeIL. 
Raleigh, N. C., Feb. 20, I916.

A beautiful life like that of your beloved wife has in reality just reached the goal for which her whole life has been the preparation.

Sincerely yours,

Louie Rutledge Feild.

Raleigh, N. C., Feb. 22, I9i6.

Your dear wife has done so much for the happiness of others, and in these good works her gentle spirit still lives to bless the world.

Your sincere friend,

Alex. J. FeIld.

\section{Raleigh, N. C., Feb. 23, i9i 6.}

She was so wonderfully beautiful in her Christian character that I can almost hear the angels singing to welcome her home.

Sincerely,

Augusta W. F. Andrews.

Charlotte, N. C., March I, I9i6.

Her friends, whose name is legion, are mourning with you in your sorrow. Through acts of unselfishness and sweet consideration of others, your wife endeared herself to all 
who were privileged to know her. She has left a permanent influence upon the community and patriotic interests.

Faithfully yours,

S. H. VAN Landingham.

Presbyterian Church of the Covenant.

Greensboro, N. C., Feb. 2 I, i 9 I 6.

I was very much distressed in seeing an account of the death of your devoted wife. So I am using this opportunity in letting you know that I sympathize with you most deepiy, and am praying that our Father will give you abundantly of His grace to sustain you in this hour of trial. May the Father of mercies and the God of all comfort be the stay of each member of your home.

Most sincerely your friend,

$$
\text { R. Murphy Williams. }
$$

Goldsboro, N. C., Feb. i9, I9i 6.

I feel it such a privilege to have known your wife, who was such a tower of strength.

Most sincerely,

MARY J. ARrington. 


\section{Linden, N. C., Feb. 2 I, I9I6.}

Hers was such a noble nature, living up to the "golden rule" in her every-day life. How sorely she will be missed!

Yours in sorrow,

Cornelia E. Elliot.

$$
\text { Belmont, N. C., Feb. 26, i9i6. }
$$

A truly noble Christian woman has gone to her reward, to receive the "Well done, faithful servant," from the lips of the Divine Master, but her beautiful example lives after her.

On several occasions we were with her at the bedside of a mutual friend, and her gentle, self-sacrificing devotion impressed us as being a woman of truly sympathetic character.

Yours in warmest sympathy,

Sisters OF MERCY, Sacred Heart Convent.

Banners Elk, Avery County,

$$
\text { Feb. 29, I9I6. }
$$

I was very much grieved to learn a few days since of the death of your beloved wife. She was so good and kind to me when I had the pleasure of being in your home, a good many years ago.

Very sincerely, Edgar TufTs. 
Crossnore, N. C., Feb. 28, i 9 i 6.

I did not know Mrs. Sprunt personally, but I was one of the many who admired her from afar.

Most sincerely yours,

$$
\text { Mary Martin Sloop. }
$$

\section{Bethany, N. C., Feb. 一, I9I6.}

How many will miss her! But she has gone where her works do follow her.

Yours most sincerely,

$$
\text { W. A. LineKer. }
$$

\section{Faisons, N. C.}

What is left to you? Why, the meaning of many years of her delightful companionship, rich harvest of good works thought out together, suffering relieved, and gladdened souls won for Christ. Truly you two have felt the brotherhood of mankind.

Your friend,

\section{Mary Lyde Hicks Williams.}

New York City, Feb. r8, r9i 6.

I am so sorry that dear Aunt Lula is dead. She was such a nice aunt to us.

With best love, Aurelie Murchison (age, 7 years). 
New York City, Feb. I9, I9 6.

I can never forget how kind Mrs. Sprunt and her family were to me in the years gone by.

$$
\begin{aligned}
& \text { Yours very sincerely, } \\
& \text { John M. DorRance. }
\end{aligned}
$$

New York City, Feb. 2 I, I 9 I 6.

It was a great privilege to have been with you and Laurence for a little while during your sorrow, and to have been able to tell you in person how deeply I feel for you.

I heard on all sides, from both white and colored people, about some kindness they had received from Aunt Lula. Lillie and I have lost our best friend and shall miss her greatly. Affectionately,

Hunter Wood.

\section{New York, Feb. 25, I9I 6.}

The memory of her life, the years of companionship, the large-hearted, generous enthusiasm, the gracious bounty, helpfulness, and hospitality, the worth and devotion of her friendships, and the steadfastness of her deeper affections - all these things, while they increase the loss and the sorrow, are consola- 
tion and compensation, because in a very real sense they can never be taken from you.

I have only spoken of your loss, but we both feel that we have lost a friend who was very close in our greatest need.

Faithfully and affectionately yours,

\section{Peyton H. Hoge.}

New YoRk, Jan. 30, I9I6.

I am deeply distressed at the news of Mrs. Sprunt's illness. Ever since I first knew her she has been my admiration.

Sincerely yours,

Emma Maffitt.

Brooklyn, N. Y., Feb. 26, i 9 I 6.

In the long years of separation in my Northern home, many beautiful things have been told me of the tender solicitations your wife had for others, and that she gave to her fellow-wayfarers on life's road the sunshine of a happy disposition and the sweetness of an unselfish love.

To Laurence and yourself the constant affection of

Yours faithfully,

JOHN B. LORD. 
Lockport, N. Y., Feb. 27, I 9 I 6.

Wilmington can ill afford to lose such a beautiful and glorious character, and this loss, I am sure, will be felt for many years.

Sincerely yours,

$$
\text { Wm. R. Kenan, JR. }
$$

Syracuse, N. Y., Feb. 26, I9I6.

It seems so short a time since she used to come with you so faithfully to the little church in Peace Dale, and now I hear that she has gone on. I feel as if something more of the sweetness and hope has been transferred from this world.

$$
\text { Yours sincerely, }
$$

$$
\text { J. W. FoвEs. }
$$

\section{Lawrence, L. I., Feb. 23 , i 9 I 6.}

Let me express deep and heartfelt sympathy for your loss and the world's loss in the departure of dear Mrs. Sprunt, long honored, revered, and beloved by all who knew her.

Most sincerely,

Philippine Feid.

$$
\text { BAltimore, MD., ——, I9 } 6 \text {. }
$$

It was hard to give Lula up; but what more could we wish for her than freedom 
from suffering and a happy reunion with her parents and daughters?

Most affectionately,

Jessie Murchison Carter.

BAltimore, Md., Feb. 20, I9i6.

Mrs. Sprunt was endeared to many by her broad sympathy and by her kindness and thoughtfulness for others. Her fortitude in trouble and high standard of right living and thinking commanded the admiration and respect of all. Those of us who had the opportunity of knowing her loved her very dearly.

Sincerely,

\section{Ralph B. Seem.}

BALtimore, MD., March 22, i9i6.

In common with every one who had the privilege of knowing your dear wife, I feel that in her going I, too, have lost a friend. Life to her, it would seem, was merely the opportunity for doing the good and kind things, and there are very many who are mourning with you.

Sincerely,

\section{Herbert L. Price.}

\section{Washington, D. C., Feb. 24, i 9 r 6.}

I wish we could express to you in some better way than words how deeply we feel for 
you in your trouble, and how full of gratitude our hearts are for all you and Aunt Lula have done for us.

With deepest sympathy and affection,

Your nephew,

James Sprunt Holmes.

Washington, D. C., Feb. 27 , I9i 6.

I know so well what your good wife has always been to you, what a wonderful help.

Affectionately,

Margaret LippitT.

Washington, D. C., Feb. 23, i 9 I 6.

I will certainly miss Aunt Luola when I come to Wilmington. She was always so sweet and kind to everybody. Every time I practice my music I work hard because she loved it so.

With lots of love,

Margaret Holmes.

Washington, D. C., March 4, i 9 i 6.

How sad it made me to hear of my sweet Mrs. Sprunt's death, but God knows us and does everything for our good, and so He must 
have wanted to release her from pain and suffering.

Affectionately, your little girl, Mar. Dev. Lippitt (age, I 2 years).

Carnegie, Pa., February -, i 9 I 6.

Such goodness and kindness as hers will be sorely missed in this world.

Very gratefully yours,

EDITH BARBER BROWN.

Seattle, Wash., March 2, i9i 6.

It is not to you alone or to your family that sorrow has come, but to the multitude of friends Mrs. Sprunt had made. I know that it must be a great comfort to you, even in the great sorrow you are experiencing, to know how beloved she was by those with whom she came in contact. She has left a legacy of character and good deeds that time cannot displace.

Sincerely yours,

Frank L. Meares.

Granger, Iowa, March 3, I 9 I 6.

I can scarcely write for tears-it is a tribute to the dear lady's life of good works.

ISOLA DANIEL. 
Los Angeles, Cal., Feb. I 7, i 9 I 6.

Edith and I are much grieved over Aunt Luola's death. She was always very dear to us, even from the first, when she came to us as your bride.

With hearts full of love and sympathy to you and Laurence from us both,

Devotedly,

James Sprunt Hall.

Plainfield, N. J., Feb. 2 i, i 9 i 6.

We grieve for and with you. Her loss will be felt far outside of the local community.

Very sincerely yours,

Malcolm McKenzie.

Atlanta, Ga., February i 9, I 9 I 6.

I shall be glad all my life that I have known such a wonderful woman as Aunt Lula was.

Devotedly,

Katherine Murchison Ellis.

Augusta, Ga., Feb. 20, I9i 6.

God has called her and her beautiful, busy life on earth is over.

Affectionately,

Janie R. Williams. 


\section{Macon, Ga., Feb. 23, I9i 6.}

I recall with much pleasure how I was impressed as a young man by the rare congeniality that existed between you and your most estimable wife.

Your loss and sorrow are great, but there is comfort to be found in the knowledge of the reward which she has received for the unusually useful and thoughtful life which was hers.

I have frequently recalled how she found her great pleasure in making others happy.

Yours sincerely,

L. W. Curtis.

Charleston, S. C., Feb. i 7, i 9 I 6.

"Seeing the King in His beauty, she says: 'Here, Lord, am I and the children Thou gavest me.',

Alexander Sprunt.

Mobile, Ala., Feb. 24, i 916.

I can hardly express to you my concern and grief when I read the announcement of your great loss in "The New York Times."

I am so glad I knew her, even so briefly. Such a character as your dear wife must be a cherished memory to those who knew her. It 
is so rarely that any one attains such perfection in this world. I cannot believe that she lived in vain. She left such a shining example behind and took such a rich endowment to the "Great Beyond."

But the greater her fitness for the other world, the greater the loss to those who loved her here. I cannot say one word of comfort. I can only voice the deep sympathy of myself and daughter.

Sincerely your friend,

Hortense A. Batrè.

LynchBURG, VA., February -, I9I6.

From afar I admired her for her manv kind and charitable deeds, her efforts to lighten and to make happy hearts bowed down with loads of grief and care, whose hand was ever ready to help and her ear to heed the cry of the needy and the distressed.

Lily VAN B. Wiggins.

Warrenton, VA., March 27, i 9 i 6.

The beautiful life of her whom numberless friends mourn, and whose acts of charity and benevolence, like milestones on the road of life, stand out as monuments to her memory, 
goes on still to serve the Creator in His endless work of the world's salvation.

My dear friend, my heart goes out to you in your great bereavement.

Your friend,

Delancy Evans.

De LAND, Fla., February -, i 9 I 6.

I wish to assure you of my sympathy and to add this word to the many which have been spoken of appreciation of Mrs. Sprunt, who has gone home.

Her life was so full of ministries that her departure will be felt more than that of most.

Cordially your friend,

\section{RichaRd ORME FLINN.}

\section{Crescent City, Fla., March i 2, i 9 i 6.}

Mrs. Sprunt was truly trusting the saving power of God, and thus the going to her was an entrance into the unspeakable glory of the presence of her Lord.

Faithfully in Him,

L. S. ChAFER.

JaCkson, Miss., March 20, 19 I 6.

My memory of her is so fresh, picturing her full of energy and bubbling life. I want 
you to know that there is one here who has not forgotten her kindness.

With love from Mrs. Lancaster and from me,

$$
\begin{aligned}
& \text { Your sincere friend, } \\
& \text { R. V. LANCASTER. }
\end{aligned}
$$

London, Feb. I 7, I9I6.

I have received your cablegram with the sad news of the death of Luola. We are very, very sorry. She will be greatly missed from the position she so adorned. I shall miss her very much.

Very affectionately yours,

$$
\text { J. D. SPRUnt. }
$$

Kelvinside, Glasgow, Scotland,

$$
\text { March I, I9I6. }
$$

Always thinking of others and never at all of her own feelings, she was a wonder unto many. Words fail me to express my admiration, love, and respect for her. I always felt happy in her presence. What a gift to possess and what a price one has to pay for such a talent! She certainly did not hide it in a napkin. I always think that those highly endowed people must suffer greatly; they feel so intensely themselves and recognize others' 
feelings so deeply that they must suffer all the time, but their interludes of freedom from care are so intensely enjoyed that it must be partly made up to them.

Ever affectionately,

TOMINA JACKSON.

Kelvinside, Glasgow, Scotland,

Feb. I8, I916.

She has been taken from us, but her memory lives on. We have all been the better for her life, and it will be with a "Well done, good and faithful servant," that she has entered the presence of her Heavenly Father.

Yours very sincerely,

WM. JACKSON.

Hillhead, Glasgow, Scotland.

Please accept all my sympathy in your great trial. Dear Luola-I am very glad that she passed away so peacefully.

Yours very affectionately and devotedly, Annie Hedderwick.

Scottish Rifles, North Camp.

I had a great admiration and respect for Cousin Luola and wished often that my fam- 
ily, but particularly my mother, could have seen more of her.

Affectionately yours,

EDWin Hedderwick.

Loudwater, Bucks, England,

March 8, I9I6.

Mrs. Sprunt held a high place in the admiration and affection of all who had the happiness of knowing her, and will ever be associated with our choice recollections of home.

Very sincerely yours,

F. L. Poisson.

Seven Kings, Essex, England,

Feb. I9, I9 6.

I shall ever remember her kind hospitality and friendship on each occasion that I visited Wilmington.

Yours sincerely,

Fred. K. Paton.

Oxton, Birkenhead, Feb. i8, igi 6.

Mrs. Sprunt's wide philanthropic and national work, which gave her so much pleasure in life, now becomes a monument, which must 
sustain and comfort you in this hour of trial, a noble and living tribute to the highest ideals of life.

Believe me,

Yours very sincerely,

C. D. Mackintosh.

\section{Nokomis, Task., Canada,}

Feb. 29, I 9 I 6.

I always remember Luola's kindness to me when I visited her at the sound.

Yours sincerely,

$$
\text { Margaret S. Cowper. }
$$

Le Havre, France, Feb. i 7, i 9 i 6.

It is doubtless a great consolation to you that she passed away so peacefully - a fitting end to a life so full of activity and of contributions to the amelioration of the needs and suffering of others.

Most sincerely yours,

TOM ORRELL.

Liverpool, England, Feb. 29, i 9 i 6. To Mr. William H. Sprunt:

Thank you for your cable informing us of Mrs. James Sprunt's death. There will be 
many individuals and institutions in Wilmington to whom her loss will make a great difference, for it seems to us that she was always busy in thought and work for others.

Your cable as to the time of the funeral enabled us to show some slight regard for her memory in closing this office on the afternoon of the 18 th.

\author{
Yours sincerely, \\ W. Milligan. \\ C. D. Mackintosh.
}

"THERE IS A PEACE THAT COMETH AFTER SORROW."

Jessie Rose Gates, in the April Century.

"There is a peace that cometh after sorrow," Of hope surrendered, not of hope fulfilled;

A peace that looketh not upon tomorrow, But calmly on a tempest that is stilled.

A peace which lives not now in joy's excesses, Nor in the happy life of love secure;

But in the unerring strength the heart possesses

Of conflicts won while learning to endure.

A peace there is in sacrifice secluded;

A life subdued, from will and passion free;

'Tis not the peace which over Eden brooded,

But that which triumphed in Gethsemane. 
Luola Murchison-Second daughter of

Colonel Kenneth McKenzie and

Katherine Elliott Williams

MurChison, was

Born near Fayetteville, North

Carolina, September 21, 1858 .

Married James SPRUNT November

27, 1883 .

Entered into rest February 17, 1916.

Children of

James and Luola Murchison Sprunt.

Kate Murchison-Born September 20, 1884.

Died March 2, 1887 .

JAmes LAurenCE-Born July 4, 1886.

Married Amoret Cameron Price June I, rgr2.

Amoret Cameron Price Sprunt died January 5, 19r5, age 24 years.

MARION MURCHISON-Born February 16, 1889.

Died August 30, r9or.

Child of

James Laurence and Amoret Cameron Price Sprunt.

JAMES LAURENCE-Born January 5, I9I5. 






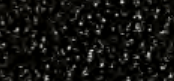

